\title{
A new Hermeuptychia (Lepidoptera, Nymphalidae, Satyrinae) is sympatric and synchronic with H. sosybius in southeast US coastal plains, while another new Hermeuptychia species - not hermes - inhabits south Texas and northeast Mexico
}

\author{
Qian Cong ${ }^{1, \dagger}$, Nick V. Grishin ${ }^{1,2, \ddagger}$ \\ I Howard Hughes Medical Institute 2 Departments of Biophysics and Biochemistry, University of Texas \\ Southwestern Medical Center, 5323 Harry Hines Blvd, Dallas, TX, USA 75390-9050 \\ † http://zoobank.org/708C6F50-8B01-4E2F-9206-948EADE4C4DD \\ $\ddagger$ http://zoobank.org/9C6FCD64-1EC4-4F7D-9E4E-ACACBA63A4A8 \\ Corresponding author: Nick V. Grishin (grishin@chop.swmed.edu) \\ Academic editor: C. Peña | Received 7 October 2013 | Accepted 24 January 2014 | Published 12 February 2014 \\ http://zoobank.org/66F2B394-4079-48E0-9A6B-90CAD8BF96F2 \\ Citation: Cong Q, Grishin NV (2014) A new Hermeuptychia (Lepidoptera, Nymphalidae, Satyrinae) is sympatric and \\ synchronic with H. sosybius in southeast US coastal plains, while another new Hermeuptychia species - not hermes - \\ inhabits south Texas and northeast Mexico. ZooKeys 379: 43-91. doi: 10.3897/zookeys.379.6394
}

\begin{abstract}
Hermeuptychia intricata Grishin, sp. n. is described from the Brazos Bend State Park in Texas, United States, where it flies synchronously with Hermeuptychia sosybius (Fabricius, 1793). The two species differ strongly in both male and female genitalia and exhibit 3.5\% difference in the COI barcode sequence of mitochondrial DNA. Setting such significant genitalic and genotypic differences aside, we were not able to find reliable wing pattern characters to tell a difference between the two species. This superficial similarity may explain why $H$. intricata, only distantly related to $H$. sosybius, has remained unnoticed until now, despite being widely distributed in the coastal plains from South Carolina to Texas, USA (and possibly to Costa Rica). Obscuring the presence of a cryptic species even further, wing patterns are variable in both butterflies and ventral eyespots vary from large to almost absent. To avoid confusion with the new species, neotype for Papilio sosybius Fabricius, 1793, a common butterfly that occurs across northeast US, is designated from Savannah, Georgia, USA. It secures the universally accepted traditional usage of this name. Furthermore, we find that DNA barcodes of Hermeuptychia specimens from the US, even those from extreme south Texas, are at least $4 \%$ different from those of $H$. hermes (Fabricius, 1775) - type local-
\end{abstract}

Copyright Qian Cong, Nick V. Grishin. This is an open access article distributed under the terms of the Creative Commons Attribution International License (CC BY 4.0), which permits unrestricted use, distribution, and reproduction in any medium, provided the original author and source are credited. 
ity Brazil: Rio de Janeiro-and suggest that the name $H$. hermes should not be used for USA populations, but rather reserved for the South American species. This conclusion is further supported by comparison of male genitalia. However, facies, genitalia and 2.1\% different DNA barcodes set Hermeuptychia populations in the lower Rio Grande Valley of Texas apart from H. sosybius. These southern populations, also found in northeastern Mexico, are described here as Hermeuptychia hermybius Grishin, sp. n. (type locality Texas: Cameron County). While being phylogenetically closer to H. sosybius than to any other Hermeuptychia species, $H$. hermybius can usually be recognized by wing patterns, such as the size of eyespots and the shape of brown lines on hindwing. "Intricate Satyr" and "South Texas Satyr" are proposed as the English names for $H$. intricata and $H$. hermybius, respectively.

\section{Keywords}

Biodiversity, cryptic species, DNA barcodes, neotropical, satyr, Hermeuptychia gisella, Hermeuptychia cucullina, Hermeuptychia sosybius kappeli, female genitalia

\section{Introduction}

What could be more exciting than a discovery of a new butterfly species? Perhaps the discovery of a butterfly species in the US that was long overlooked, completely unexpected, and has closest named relatives far away in Bolivia and Brazil. These finds may not be easy to come by, because most of such species are cryptic and appear superficially similar to their more common and well-known relatives. However, DNA-based techniques introduced in taxonomy during the last few decades offer viable tools to facilitate discovery of cryptic species (Bickford et al. 2007).

The genus Hermeuptychia was proposed by Forster (1964) on the basis of male genitalia to circumscribe a group of close relatives hardly separable by highly variable wing patterns, but distinct in male genitalia. Lamas (2004) recognized eight named species of Hermeuptychia and suggested the existence of several unnamed species in Colombia and Peru. A recent comparative study of DNA barcodes and morphology of male genitalia from all parts of Hermeuptychia range revealed congruence between classifications by barcodes and genitalia, hypothesized that $H$. gisella (Hayward, 1957) is a species distinct from H. cucullina (Weymer, 1911), and discussed several unnamed species in Brazil (Seraphim et al. 2014). Interestingly, specimens with barcodes and genitalia similar to H. hermes (Fabricius, 1775) - type locality Brazil: Rio de Janeirowere not found north of Costa Rica. Most importantly for this work, Seraphim et al. (2014) outlined several distinct molecular and morphological groups of species, assigned existing names to these groups, illustrated their genitalia and listed genitalia characters in their Table 1. All Hermeuptychia specimens from the US (North Carolina, Tennessee and Florida) used by Seraphim et al. (2014) possessed similar DNA barcode sequences and were assigned to morphogroup 4 by male genitalia.

Here, we show that two distinct species from two different morphogroups as defined by Seraphim et al. (2014) fly together at the same location in Texas on the same day. These two species possess very different genitalia in both sexes and 3.5\% difference in DNA barcodes. One of these species has traditionally been called $H$. sosybius 
(Fabricius, 1793) and the neotype for it is designated herein. The second species is apparently new, and is from the same molecular group with South American species $H$. cucullina (from Peru and Bolivia) and H. gisella (from Bolivia and Brazil). This new species is described, discussed and illustrated. Furthermore, we find that DNA barcodes of Hermeuptychia from the lower Rio Grande Valley region of Texas (Webb, Zapata, Starr, Hidalgo, and Cameron Counties) form a tight cluster and differ by at least $2 \%$ from the barcodes of over $50 \mathrm{H}$. sosybius specimens (divergence average $0.09 \%$, standard deviation $0.19 \%$, maximum below $1 \%$ ) across its range from North Carolina to Texas (south to Uvalde, Comal, Guadalupe and Brazoria Counties). In addition to DNA barcodes, these south Texas Hermeuptychia populations differ from $H$. sosybius by wing patterns and male genitalia (subtly, but quantifiably) and are described here as another new species, bringing the total count of USA Hermeuptychia species to three.

\section{Materials and methods}

Specimens used in this study were collected in the field under the permit \#08-02Rev from Texas Parks and Wildlife Department to NVG, and inspected in the following collections: Texas A\&M University Insect Collection, College Station, TX (TAMU); National Museum of Natural History, Smithsonian Institution, Washington, DC (USNM); Natural History Museum, London, UK (BMNH). Standard entomological techniques were used for dissection (Robbins 1991), i.e. abdomen was broken off, soaked for 40 minutes (or until ready) in $10 \% \mathrm{KOH}$ at $60{ }^{\circ} \mathrm{C}$ (or overnight at room temperature), dissected, and subsequently stored in a small glycerol-filled vial on the pin under the specimen. Genitalia and wing venation terminology follows Steinhauser (1981). Length measurements are in metric units and were made from photographs of specimens taken with a scale and magnified on a computer screen. Photographs of immature stages were taken by NVG using Minolta Maxxum 500si 35mm SLR film camera through a $90 \mathrm{~mm} \mathrm{f} / 2.8$ Tamron SP AF Macro lens (for smaller objects additionally with a Phoenix C/D7 AF 2X Teleconverter) on Kodachrome 25 or Fuji Velvia 50 slide films and slides were scanned using Nikon Super CoolScan 5000 ED film scanner. Photographs of specimens were taken with a Nikon D800 camera through a $105 \mathrm{~mm}$ f/2.8G AF-S VR Micro-Nikkor lens; dissected genitalia were photographed in glycerol with a Nikon D200 camera without a lens and through microscopes at $4 \times-$ $5 \times$ magnification. Images were assembled and edited in Photoshop CS5.1. Genitalic photographs were taken in several focus slices and stacked in Photoshop to increase depth of field.

Two legs (cut with scissors into tiny pieces in lysis buffer) of freshly collected specimens, or two legs that were removed from freshly collected specimens and preserved in alcohol for several years, or an abdomen (dropped into lysis buffer as a whole, and after overnight incubation at $56^{\circ} \mathrm{C}$ transferred into $10 \% \mathrm{KOH}$ for genitalia dissection) of older specimens were used to extract genomic DNA with QIAGEN DNeasy blood and tissue kit complemented with EconoSpin columns from Epoch, or Macherey- 
Nagel (MN) NucleoSpin ${ }^{\circledast}$ tissue kit following the manufacturer’s protocol. Genomic DNA was eluted in a total volume of 120-150 $\mu$ QIAGEN AE buffer (concentration of DNA as measured by Promega QuantiFluor ${ }^{\circledR} \mathrm{dsDNA}$ System was from 0.01 to 2.5 $\mathrm{ng} / \mu \mathrm{l}$ for legs and from 0.005 to $30 \mathrm{ng} / \mu \mathrm{l}$ for abdomens, depending on specimen age and storage conditions) and was stored at $-20{ }^{\circ} \mathrm{C}$.

PCR was performed using Invitrogen AmpliTaq Gold 360 master mix in a $20 \mu \mathrm{l}$ total volume containing less than $10 \mathrm{ng}$ of template DNA and $0.5 \mu \mathrm{M}$ of each primer. For legs from freshly collected specimens or those preserved in alcohol, the following primers were used to obtain the complete barcode: LepF: 5'-TGTAAAACGACGGCCAGTATTCAACCAATCATAAAGATATTGG-3'and LepR: 5'-CAGGAAACAGCTATGACCTAAACTTCTGGATGTCCAAAAAATCA-3’. For older specimens the following pairs of primers were used: sCOIF (forward, 5'-ATTCAACCAATCATAAAGATATTGG-3') - smCOIR (reverse, 5'-CCTGTTCCAGCTCCATTTTC-3') and bat-smCOIF (forward, 5'-GCTTTTCCTCGTATAAATAATA-3') - sCOIR (reverse, 5'-TAAACTTCTGGATGTCCAAAAAATCA-3'), to amplify barcode in two overlapping segments (307, $408 \mathrm{bp})$.

The barcodes of the $H$. sosybius neotype (designated below) and $H$. hermes kappeli Anken, 1993 holotype were amplified in four overlapping segments with the following four pairs of Hermeuptychia-specific primers: styr-COIF (forward, 5'-CAACCAATCATAAAGATATTGGAAC-3') - styr-bCOIR (reverse, 5'-AAAATTATAATAAAAGCATGRGCTGT-3'), styr-bCOIF (forward, 5'-YCCAGGATTTTTAATTGGAGATG-3') - styr-mCOIR (reverse, 5'-CCTGTYCCACTTCCATTTTCTAC-3'), styr-mCOIF (forward, 5'-TTTTGATTATTACCYCCATCTTT-3') - styr-eCOIR (reverse, 5'-TTCCTACAGCTCAAATAAATAAAGG-3'), and styreCOIF (forward, 5'-TTCATTTAGCTGGAATTTCWTCAA-3') - sCOIR (reverse, 5'-TAAACTTCTGGATGTCCAAAAAATCA-3').

For very old specimens (e.g., from 1898 to 1944), amplification of longer DNA segments failed. To obtain their sequences for identification, we developed Hermeuptychia-specific primers for very short, about 100 bp fragments, which we call ID tags. Two regions, in which the three USA Hermeuptychia species differ from each other the most, were selected and the following primers were designed: styr-ID1F (forward, 5'-TTGAGCAGGAATAATTGGWACAT-3') - styr-ID1R (reverse, 5'-AAAAGCATGRGCTGTAACAA-3') and styr-ID2F (forward, 5'-TTGGAGGATTTGGTAATTGACTT-3') - styr-ID2R (reverse, 5’-AAAGATGGRGGTAATAATCAAAAT-3') to amplify 75 and 56 bp sequence from the specimen (together with both primers, the actual products are 118 and $103 \mathrm{bp}$ ).

These primers yielded clear DNA sequence traces (Fig. 65) for 11 out of 12 specimens. The failed traces from DNA voucher 13386A05 showed signs of contamination (i.e., multiple peaks at many positions, probably not even a Hermeuptychia sequence) and were inconclusive. Genitalia, however, offered unambiguous identification of this specimen. We did not pursue re-extraction of DNA from the 13386A05 specimen and were satisfied with higher than $90 \%$ success rate (11 out of 12) of this method. The oldest specimens from 1898 and likely prior to 1896 (date not specified on the 
label of the second specimen, and 1896 is the date of collection donation) yielded excellent traces (e.g., Fig. 65). 6, 1 and 4 specimens of each of the three species were sequenced. For DNA extraction and PCR reactions, they were intermixed and ordered not by species, but as they were placed in USNM collection by curators who did not suspect the presence of more than one species (i.e. semi-randomly, according to DNA voucher numbers assigned to them). Because cross-contamination frequently happens between adjacent specimens, this arrangement alleviates biasing DNA conclusions on the basis of our genitalia and wing pattern-based identification. I.e., if adjacent specimens are the same species (and thus are likely to possess the same DNA barcode), it is more difficult to detect cross-contamination from neighbors. However, if they are different species, disagreement between genitalia-based identification and DNA-based identification would raise suspicions of cross-contamination. All 11 successful DNA identifications were invariably the same as identifications on the basis of genitalia and wing patterns (the voucher 15609E04, Fig. 44, lacked abdomen), and agreed with geographic distribution of these species.

PCR reaction was cleaned up by enzymatic digestion for the whole barcode amplifications of DNA from freshly collected or alcohol preserved specimens and ID tag amplification of old specimens with $4 \mu \mathrm{l}$ Shrimp Alkaline Phosphatase (20 U/ $\mu \mathrm{l})$ and $1 \mathrm{ul}$ Exonuclease I $(1 \mathrm{U} / \mu \mathrm{l})$ from New England Biolabs. For older specimens that are barcoded in multiple segments, due to the frequent presence of primer dimers and other short non-specific PCR products, Agencourt Ampure XP beads or Invitrogen $\mathrm{E}-\mathrm{Gel}^{\circ} \mathrm{EX}$ Agarose Gels (followed by Zymo gel DNA recovery kit) were used to select the DNA products of expected length. Sequences were obtained using the M13 primers (for amplification from LepF and LepR primers): 5'-TGTAAAACGACGGCCAGT-3' or 5'-CAGGAAACAGCTATGACC-3' or with primers used in PCR. For the ID tags, PCR products were sequenced in both directions. Sanger sequencing was performed with Applied Biosystems Big Dye Terminator 3.1 kit on ABI capillary instrument in the DNA Sequencing Core Facility of the McDermott Center at UT Southwestern. The resulting sequence traces were proofread in FinchTV <http://www.geospiza.com/Products/finchtv.shtml>. We obtained complete or partial DNA barcode sequences from 85 Hermeuptychia specimens. Sequences and accompanying specimen data were submitted to GenBank and received accession numbers KJ025523-KJ025607. Data about these specimens are provided in Table 1.

Additional DNA sequences were downloaded from GenBank <http://genbank. gov/> using accession numbers provided in Seraphim et al. (2014) or were found by BLAST <http://blast.ncbi.nlm.nih.gov/> searches using sequences obtained by us to query "nr/nt" database. Information about specimens with sequences used in this study is in Table 1 . All sequences were aligned manually since they matched throughout their length without insertions or deletions, and analyzed using the Phylogeny.fr server at <http://www.phylogeny.fr/> with default parameters (Dereeper et al. 2008), namely, Kimura 2-parameters model (Kimura 1980) was used to compute evolutionary distances from aligned DNA sequences and BioNJ (Gascuel 1997) algorithm was used to build trees. 
Table I. Data for specimens with DNA sequences used in this study.

\begin{tabular}{|c|c|c|c|c|c|}
\hline Species & Voucher & GenBank & Locality & Date & Collector \\
\hline H. sosybius & NVG-696 & KJ025523 & $\begin{array}{c}\text { OK: Atoka Co., } 13 \text { air mi E of Atoka, } \\
34.41186-95.91044,225 \mathrm{~m}\end{array}$ & 29-Aug-2009 & Nick V. Grishin \\
\hline H. sosybius & NVG-1632 & KJ025524 & $\begin{array}{l}\text { TX: Lamar Co., } 11.5 \text { air mi NW of } \\
\text { Paris, FM1499 @ Sanders Cr., } 140 \text { m }\end{array}$ & 25-Apr-1998 & Nick V. Grishin \\
\hline H. sosybius & NVG-1630 & KJ025525 & TX: Marion Co., nr. Carter L., 50 m & 28-Sep-1996 & Nick V. Grishin \\
\hline H. sosybius & NVG-1633 & KJ025526 & TX: Marion Co., nr. Carter L., 50 m & 29-Sep-1996 & Nick V. Grishin \\
\hline H. sosybius & NVG-1606 & KJ025527 & $\begin{array}{l}\text { TX: Wise Co., LBJ National Grassland, } \\
300 \mathrm{~m}\end{array}$ & 3-Aug-1998 & Nick V. Grishin \\
\hline H. sosybius & NVG-783 & KJ025528 & TX: Tyler Co., John H. Kirby SF, 40 m & 19-Mar-2011 & Nick V. Grishin \\
\hline H. sosybius & NVG-784 & KJ025529 & TX: Tyler Co., John H. Kirby SF, 40 m & 19-Mar-2011 & Nick V. Grishin \\
\hline H. sosybius & NVG-785 & KJ025530 & TX: Tyler Co., John H. Kirby SF, 40 m & 19-Mar-2011 & Nick V. Grishin \\
\hline H. sosybius & NVG-786 & KJ025531 & TX: Tyler Co., John H. Kirby SF, 40 m & 19-Mar-2011 & Nick V. Grishin \\
\hline H. sosybius & NVG-1537 & KJ025532 & $\begin{array}{l}\text { TX: Fort Bend Co., Brazos Bend SP, } \\
\text { Horseshoe L. tr., } 29.38193-95.61141 \text {, } \\
15 \mathrm{~m}\end{array}$ & 17-Aug-2013 & Nick V. Grishin \\
\hline H. sosybius & NVG-1538 & KJ025533 & $\begin{array}{l}\text { TX: Fort Bend Co., Brazos Bend SP, } \\
\text { Horseshoe L. tr., } 29.38193-95.61141 \text {, } \\
15 \mathrm{~m}\end{array}$ & 17-Aug-2013 & Nick V. Grishin \\
\hline H. sosybius & NVG-1539 & KJ025534 & $\begin{array}{l}\text { TX: Fort Bend Co., Brazos Bend SP, } \\
\text { Horseshoe L. tr., } 29.38193-95.61141 \text {, } \\
15 \mathrm{~m}\end{array}$ & 17-Aug-2013 & Nick V. Grishin \\
\hline H. sosybius & NVG-1540 & KJ025535 & $\begin{array}{l}\text { TX: Fort Bend Co., Brazos Bend SP, } \\
\text { Horseshoe L. tr., } 29.38193-95.61141 \text {, } \\
15 \mathrm{~m}\end{array}$ & 17-Aug-2013 & Nick V. Grishin \\
\hline H. sosybius & NVG-1542 & KJ025536 & $\begin{array}{l}\text { TX: Fort Bend Co., Brazos Bend SP, } \\
\text { Horseshoe L. tr., } 29.38193-95.61141 \text {, } \\
15 \mathrm{~m}\end{array}$ & 17-Aug-2013 & Nick V. Grishin \\
\hline H. sosybius & NVG-1543 & KJ025537 & $\begin{array}{l}\text { TX: Fort Bend Co., Brazos Bend SP, } \\
\text { Horseshoe L. tr., } 29.38193-95.61141 \text {, } \\
15 \mathrm{~m}\end{array}$ & 17-Aug-2013 & Nick V. Grishin \\
\hline H. sosybius & NVG-1544 & KJ025538 & $\begin{array}{c}\text { TX: Fort Bend Co., Brazos Bend SP, } \\
\text { Horseshoe L. tr., } 29.38193-95.61141 \text {, } \\
15 \mathrm{~m}\end{array}$ & 17-Aug-2013 & Nick V. Grishin \\
\hline H. sosybius & NVG-1545 & KJ025539 & $\begin{array}{l}\text { TX: Fort Bend Co., Brazos Bend SP, } \\
\text { Horseshoe L. tr., } 29.38193-95.61141 \text {, } \\
15 \mathrm{~m}\end{array}$ & 17-Aug-2013 & Nick V. Grishin \\
\hline H. sosybius & NVG-1546 & KJ025540 & $\begin{array}{l}\text { TX: Fort Bend Co., Brazos Bend SP, } \\
\text { Horseshoe L. tr., } 29.38193-95.61141 \text {, } \\
15 \mathrm{~m}\end{array}$ & 17-Aug-2013 & Nick V. Grishin \\
\hline H. sosybius & NVG-1547 & KJ025541 & $\begin{array}{c}\text { TX: Fort Bend Co., Brazos Bend SP, } \\
\text { Horseshoe L. tr., } 29.38193-95.61141 \text {, } \\
15 \mathrm{~m}\end{array}$ & 17-Aug-2013 & Nick V. Grishin \\
\hline H. sosybius & NVG-1549 & KJ025542 & $\begin{array}{c}\text { TX: Fort Bend Co., Brazos Bend SP, } \\
\text { Horseshoe L. tr., } 29.38193-95.61141 \text {, } \\
15 \mathrm{~m}\end{array}$ & 17-Aug-2013 & Nick V. Grishin \\
\hline H. sosybius & NVG-1550 & KJ025543 & $\begin{array}{l}\text { TX: Fort Bend Co., Brazos Bend SP, } \\
\text { Horseshoe L. tr., } 29.38193-95.61141 \text {, } \\
15 \mathrm{~m}\end{array}$ & 17-Aug-2013 & Nick V. Grishin \\
\hline H. sosybius & NVG-1552 & KJ025544 & $\begin{array}{l}\text { TX: Fort Bend Co., Brazos Bend SP, } \\
\text { Horseshoe L. tr., } 29.38193-95.61141 \text {, } \\
15 \mathrm{~m}\end{array}$ & 17-Aug-2013 & Nick V. Grishin \\
\hline H. sosybius & NVG-1553 & KJ025545 & $\begin{array}{l}\text { TX: Fort Bend Co., Brazos Bend SP, } \\
\text { Horseshoe L. tr., } 29.38193-95.61141 \text {, } \\
15 \mathrm{~m}\end{array}$ & 17-Aug-2013 & Nick V. Grishin \\
\hline H. sosybius & NVG-1557 & KJ025546 & $\begin{array}{c}\text { TX: Fort Bend Co., Brazos Bend SP, nr. } \\
\text { Hale L., 29.38008 -95.58473, } 16 \text { m }\end{array}$ & 17-Aug-2013 & Nick V. Grishin \\
\hline
\end{tabular}




\begin{tabular}{|c|c|c|c|c|c|}
\hline Species & Voucher & GenBank & Locality & Date & Collector \\
\hline H. sosybius & NVG-1559 & KJ025547 & $\begin{array}{l}\text { TX: Fort Bend Co., Brazos Bend SP, nr. } \\
\text { Hale L., 29.38008 }-95.58473,16 \text { m }\end{array}$ & 17-Aug-2013 & Nick V. Grishin \\
\hline H. sosybius & NVG-1561 & KJ025548 & $\begin{array}{c}\text { TX: Fort Bend Co., Brazos Bend SP, nr. } \\
\text { Hale L., 29.38008 - } 95.58473,16 \text { m }\end{array}$ & 17-Aug-2013 & Nick V. Grishin \\
\hline H. sosybius & NVG-1562 & KJ025549 & $\begin{array}{c}\text { TX: Fort Bend Co., Brazos Bend SP, nr. } \\
\text { Hale L., 29.38008 - } 95.58473,16 \mathrm{~m}\end{array}$ & 17-Aug-2013 & Nick V. Grishin \\
\hline H. sosybius & NVG-1564 & KJ025550 & $\begin{array}{c}\text { TX: Fort Bend Co., Brazos Bend SP, nr. } \\
\text { Hale L., 29.38008 }-95.58473,16 \mathrm{~m}\end{array}$ & 17-Aug-2013 & Nick V. Grishin \\
\hline H. sosybius & NVG-1566 & KJ025551 & $\begin{array}{l}\text { TX: Fort Bend Co., Brazos Bend SP, nr. } \\
\text { Hale L., 29.38008 -95.58473, } 16 \text { m }\end{array}$ & 17-Aug-2013 & Nick V. Grishin \\
\hline H. sosybius & NVG-1567 & KJ025552 & $\begin{array}{l}\text { TX: Fort Bend Co., Brazos Bend SP, nr. } \\
\text { Hale L., 29.38008 -95.58473, } 16 \mathrm{~m}\end{array}$ & 17-Aug-2013 & Nick V. Grishin \\
\hline H. sosybius & $13385 \mathrm{H} 04$ & KJ025553 & TX: Comal Co., New Braunfels & 3-Oct-1981 & \\
\hline H. sosybius & $13385 \mathrm{H} 11$ & KJ025554 & TX: Williamson Co., Florence & 3-Sep-1974 & J. Parkinson \\
\hline H. sosybius & $13385 \mathrm{H} 03$ & KJ025555 & TX: Uvalde Co., Utopia & 10-Jun-1992 & $\begin{array}{l}\text { D. E. Gaskin \& } \\
\text { EAL }\end{array}$ \\
\hline H. sosybius & $13385 \mathrm{H} 05$ & KJ025556 & TX: Uvalde Co., Utopia & $\begin{array}{l}\{9-23\}-S e p- \\
1994\end{array}$ & $\begin{array}{l}\text { D. E. Gaskin \& } \\
\text { EAL }\end{array}$ \\
\hline H. sosybius & $13385 \mathrm{H} 06$ & KJ025557 & TX: Uvalde Co., Utopia & $\begin{array}{c}\{9-23\}-S e p- \\
1994\end{array}$ & $\begin{array}{l}\text { D. E. Gaskin \& } \\
\text { EAL }\end{array}$ \\
\hline H. sosybius & $13385 \mathrm{H} 07$ & KJ025558 & TX: Uvalde Co., Utopia & $\begin{array}{l}\{13-22\}-A p r- \\
1995\end{array}$ & D. E. Gaskin \\
\hline H. sosybius & $13385 \mathrm{H} 08$ & KJ025559 & TX: Uvalde Co., Utopia & $\begin{array}{l}\{13-22\}-A p r- \\
1995\end{array}$ & D. E. Gaskin \\
\hline H. sosybius & $13385 \mathrm{G} 12$ & KJ025560 & $\begin{array}{c}\text { FL: Highlands Co., Lake Placid, } \\
\text { Archbold Biological Station }\end{array}$ & 17-Feb-1985 & D. C. Ferguson \\
\hline H. sosybius* & 13386A07 & KJ025561 & GA: Chatham Co., Savannah & 28-Jul-1958 & $\begin{array}{l}\text { Coll. Gordon } \\
\text { B. Small }\end{array}$ \\
\hline H. sosybius ${ }^{* *}$ & NVG-1845 & KJ025562 & FL: $\mathrm{N}$ of L. Okeechobee & 29-Mar-1983 & Ralf H. Anken \\
\hline H. sosybius & 15609E04 & KJ025563 & FL: Pinellas Co., St. Petersburg & 3-Nov-1938 & H. E. Wilford \\
\hline H. sosybius & $13385 \mathrm{G} 10$ & KJ025564 & SC: Clarendon Co. & Aug-1909 & \\
\hline H. sosybius & $13385 \mathrm{H} 09$ & KJ025565 & TX: Bastrop Co., Bastrop & prior to 1896 & $\begin{array}{c}\text { Collection of } \\
\text { O. Meske }\end{array}$ \\
\hline H. sosybius & 13386A01 & KJ025566 & TX: Guadalupe Co., Seguin & 26-Oct-1905 & F. C. Pratt \\
\hline H. sosybius & 13386A04 & KJ025567 & LA: Jackson Parish, Jonesboro & 4-Jun-1920 & G. W. Rawson \\
\hline H. sosybius & 13386A06 & KJ025568 & LA: Jefferson Parish, Harahan & 11-Aug-1944 & W. D. Field \\
\hline H. hermybius & NVG-1603 & KJ025569 & TX: Cameron Co., E of Brownsville & 17-Mar-2003 & Nick V. Grishin \\
\hline H. hermybius & NVG-1607 & KJ025570 & TX: Cameron Co., E of Brownsville & 18-Jan-2003 & Nick V. Grishin \\
\hline H. hermybius & NVG-1609 & KJ025571 & TX: Cameron Co., E of Brownsville & 30-Mar-2003 & Nick V. Grishin \\
\hline H. hermybius & NVG-1610 & KJ025572 & TX: Cameron Co., E of Brownsville & 9-Mar-2003 & Nick V. Grishin \\
\hline H. hermybius & NVG-1611 & KJ025573 & TX: Cameron Co., E of Brownsville & 14-Mar-2003 & Nick V. Grishin \\
\hline H. hermybius & NVG-1612 & KJ025574 & TX: Cameron Co., E of Brownsville & 16-Mar-2003 & Nick V. Grishin \\
\hline H. hermybius & NVG-1628 & KJ025575 & TX: Cameron Co., E of Brownsville & 19-Oct-1997 & Nick V. Grishin \\
\hline H. hermybius & NVG-1695 & KJ025576 & $\begin{array}{c}\text { TX: Hidalgo Co., } 1.5 \text { air mi SE of } \\
\text { Relampago, Rio Rico Rd., } 26.07 \\
-97.891,21 \mathrm{~m}\end{array}$ & 19-Oct-2013 & $\begin{array}{l}\text { William R. } \\
\text { Dempwolf }\end{array}$ \\
\hline H. hermybius & NVG-1698 & KJ025577 & $\begin{array}{c}\text { TX: Hidalgo Co., } 1.5 \text { air mi SE of } \\
\text { Relampago, Rio Rico Rd., } 26.07 \\
-97.891,21 \mathrm{~m}\end{array}$ & 19-Oct-2013 & $\begin{array}{l}\text { William R. } \\
\text { Dempwolf }\end{array}$ \\
\hline H. hermybius & NVG-1699 & KJ025578 & $\begin{array}{l}\text { TX: Hidalgo Co., } 1.5 \text { air mi SE of } \\
\text { Relampago, Rio Rico Rd., } 26.07 \\
-97.891,21 \mathrm{~m}\end{array}$ & 19-Oct-2013 & $\begin{array}{l}\text { William R. } \\
\text { Dempwolf }\end{array}$ \\
\hline H. hermybius & NVG-1712 & KJ025579 & $\begin{array}{l}\text { TX: Starr Co., Rio Grande City, Fort } \\
\text { Ringgold, 26.3707 -98.8064, } 45 \text { m }\end{array}$ & 20-Oct-2013 & $\begin{array}{l}\text { William R. } \\
\text { Dempwolf }\end{array}$ \\
\hline H. hermybius & NVG-1714 & KJ025580 & $\begin{array}{l}\text { TX: Starr Co., Rio Grande City, Fort } \\
\text { Ringgold, 26.3707 -98.8064, } 45 \text { m }\end{array}$ & 20-Oct-2013 & $\begin{array}{l}\text { William R. } \\
\text { Dempwolf }\end{array}$ \\
\hline
\end{tabular}




\begin{tabular}{|c|c|c|c|c|c|}
\hline Species & Voucher & GenBank & Locality & Date & Collector \\
\hline H. hermybius & NVG-1726 & KJ025581 & $\begin{array}{c}\text { TX: Starr Co., Roma, S of Roma } \\
\text { International Bridge, } 26.4035 \\
-99.0175,50 \mathrm{~m}\end{array}$ & 20-Oct-2013 & $\begin{array}{l}\text { William R. } \\
\text { Dempwolf }\end{array}$ \\
\hline H. hermybius & NVG-1727 & KJ025582 & $\begin{array}{c}\text { TX: Starr Co., Roma, S of Roma } \\
\text { International Bridge, } 26.4035 \\
-99.0175,50 \mathrm{~m}\end{array}$ & 20-Oct-2013 & $\begin{array}{l}\text { William R. } \\
\text { Dempwolf }\end{array}$ \\
\hline H. hermybius & NVG-1735 & KJ025583 & $\begin{array}{c}\text { TX: Starr Co., } 0.5 \mathrm{mi} \mathrm{S} \text { of Fronton, } \\
26.399-99.085,50 \mathrm{~m}\end{array}$ & 20-Oct-2013 & $\begin{array}{l}\text { William R. } \\
\text { Dempwolf }\end{array}$ \\
\hline H. hermybius & NVG-1737 & KJ025584 & $\begin{array}{c}\text { TX: Starr Co., } 0.5 \mathrm{mi} \mathrm{S} \text { of Fronton, } \\
26.399-99.085,50 \mathrm{~m}\end{array}$ & 20-Oct-2013 & $\begin{array}{l}\text { William R. } \\
\text { Dempwolf }\end{array}$ \\
\hline H. hermybius & NVG-1747 & KJ025585 & $\begin{array}{c}\text { TX: Starr Co., Salineno @ Rio Grande, } \\
26.51463-99.11633,53 \mathrm{~m}\end{array}$ & 23-Oct-2013 & $\begin{array}{l}\text { William R. } \\
\text { Dempwolf }\end{array}$ \\
\hline H. hermybius & NVG-1635 & KJ025586 & $\begin{array}{c}\text { TX: Zapata Co., San Ygnacio @ Rio } \\
\text { Grande, } 92 \mathrm{~m} \\
\end{array}$ & 7-Oct-2007 & Nick V. Grishin \\
\hline H. hermybius & $13385 \mathrm{H} 10$ & KJ025587 & TX: Webb Co., Laredo & 15-Apr-1949 & E. L. Todd \\
\hline H. intricata & NVG-1541 & KJ025588 & $\begin{array}{c}\text { TX: Fort Bend Co., Brazos Bend SP, } \\
\text { Horseshoe L. tr., } 29.38193-95.61141 \text {, } \\
15 \mathrm{~m}\end{array}$ & 17-Aug-2013 & Nick V. Grishin \\
\hline H. intricata & NVG-1548 & KJ025589 & $\begin{array}{c}\text { TX: Fort Bend Co., Brazos Bend SP, } \\
\text { Horseshoe L. tr., } 29.38193-95.61141 \text {, } \\
15 \mathrm{~m}\end{array}$ & 17-Aug-2013 & Nick V. Grishin \\
\hline H. intricata & NVG-1551 & KJ025590 & $\begin{array}{l}\text { TX: Fort Bend Co., Brazos Bend SP, } \\
\text { Horseshoe L. tr., } 29.38193 \text {-95.61141, } \\
15 \mathrm{~m}\end{array}$ & 17-Aug-2013 & Nick V. Grishin \\
\hline H. intricata & NVG-1554 & KJ025591 & $\begin{array}{c}\text { TX: Fort Bend Co., Brazos Bend SP, nr. } \\
\text { Hale L., 29.38008 -95.58473, } 16 \mathrm{~m}\end{array}$ & 17-Aug-2013 & Nick V. Grishin \\
\hline H. intricata & NVG-1555 & KJ025592 & $\begin{array}{l}\text { TX: Fort Bend Co., Brazos Bend SP, nr. } \\
\text { Hale L., 29.38008 - } 95.58473,16 \text { m }\end{array}$ & 17-Aug-2013 & Nick V. Grishin \\
\hline H. intricata & NVG-1556 & KJ025593 & $\begin{array}{c}\text { TX: Fort Bend Co., Brazos Bend SP, nr. } \\
\text { Hale L., 29.38008 -95.58473, } 16 \mathrm{~m}\end{array}$ & 17-Aug-2013 & Nick V. Grishin \\
\hline H. intricata & NVG-1558 & KJ025594 & $\begin{array}{c}\text { TX: Fort Bend Co., Brazos Bend SP, nr. } \\
\text { Hale L., 29.38008 }-95.58473,16 \text { m }\end{array}$ & 17-Aug-2013 & Nick V. Grishin \\
\hline H. intricata* & NVG-1560 & KJ025595 & $\begin{array}{c}\text { TX: Fort Bend Co., Brazos Bend SP, nr. } \\
\text { Hale L., 29.38008 -95.58473, } 16 \text { m }\end{array}$ & 17-Aug-2013 & Nick V. Grishin \\
\hline H. intricata & NVG-1563 & KJ025596 & $\begin{array}{c}\text { TX: Fort Bend Co., Brazos Bend SP, nr. } \\
\text { Hale L., } 29.38008-95.58473,16 \mathrm{~m}\end{array}$ & 17-Aug-2013 & Nick V. Grishin \\
\hline H. intricata & NVG-1565 & KJ025597 & $\begin{array}{l}\text { TX: Fort Bend Co., Brazos Bend SP, nr. } \\
\text { Hale L., } 29.38008-95.58473,16 \mathrm{~m}\end{array}$ & 17-Aug-2013 & Nick V. Grishin \\
\hline H. intricata & NVG-1629 & KJ025598 & $\begin{array}{l}\text { TX: San Jacinto Co., Sam Houston NF, } \\
\text { USF217 @ Big Creek, } 58 \text { m }\end{array}$ & 12-Apr-1998 & Nick V. Grishin \\
\hline H. intricata & NVG-1631 & KJ025599 & $\begin{array}{l}\text { TX: Brazoria Co., Bar-X Ranch, Rd. } \\
\text { 971N, 29.13252 -95.58340, } 7 \mathrm{~m}\end{array}$ & 4-Mar-2000 & Nick V. Grishin \\
\hline H. intricata & 13385G07 & KJ025600 & $\begin{array}{c}\text { SC: Charleston Co., McClellanville, } \\
\text { Wedge Plantation }\end{array}$ & 6-Apr-1970 & D. C. Ferguson \\
\hline H. intricata & $13385 \mathrm{H} 01$ & KJ025601 & FL: Alachua Co., Gainesville & 12-Mar-1983 & Scott W. Gross \\
\hline H. intricata & $13385 \mathrm{H} 02$ & KJ025602 & FL: "Putnam Co | Shell Bluff Landing" & 29-Sep-1985 & George Balogh \\
\hline H. intricata & 13386A03 & KJ025603 & LA: Jefferson Parish, Harahan & 28-Jun-1944 & W. D. Field \\
\hline H. intricata & 13385G08 & KJ025604 & SC: Clarendon Co. & 9-Aug-1898 & \\
\hline H. intricata & 13385G09 & KJ025605 & SC: Clarendon Co. & Aug-1910 & \\
\hline H. intricata & 13385G11 & KJ025606 & SC: Clarendon Co. & Aug-1910 & \\
\hline H. intricata & $13386 A 02$ & KJ025607 & "Flatbush LI" & prior to 1941 & $\begin{array}{l}\text { G. P. Engelhardt } \\
\text { Coll. }\end{array}$ \\
\hline H. sosybius & $\begin{array}{c}\text { DNA- } \\
\text { ATBI-0799 } \\
\end{array}$ & GU089906* & $\begin{array}{c}\text { NC: Swain Co., AN9, Smokemont } \\
\text { Stables, 35.5504-83.3084 }\end{array}$ & 20-Jul-2004 & R. M. Pyle \\
\hline H. sosybius & NSHer-EUA07 & KF466083* & TN: Rutheford Co., $35.70-86.33$ & 2009 & A. V. Z. Brower \\
\hline H. sosybius & NSHer-EUA08 & KF466084* & TN: Rutheford Co., $35.70-86.33$ & 2009 & A. V. Z. Brower \\
\hline
\end{tabular}




\begin{tabular}{|c|c|c|c|c|c|}
\hline Species & Voucher & GenBank & $\begin{array}{l}\text { Locality } \\
\end{array}$ & Date & Collector \\
\hline H. sosybius & $\begin{array}{c}\text { DNA- } \\
\text { ATBI-0847 }\end{array}$ & GU089907* & $\begin{array}{l}\text { TN: Blount Co. AN2, Cades Cove, } \\
\text { along Forge Cr. Rd. } 35.583-83.838\end{array}$ & 20-Jul-2004 & R. M. Pyle \\
\hline H. sosybius & $\begin{array}{c}\text { DNA- } \\
\text { ATBI-0848 }\end{array}$ & GU089908* & $\begin{array}{l}\text { TN: Blount Co. AN2, Cades Cove, } \\
\text { along Forge Cr. Rd. } 35.583-83.838\end{array}$ & 20-Jul-2004 & R. M. Pyle \\
\hline H. sosybius & $\begin{array}{c}\text { DNA- } \\
\text { ATBI-0849 }\end{array}$ & GU089909* & $\begin{array}{l}\text { TN: Blount Co. AN2, Cades Cove, } \\
\text { along Forge Cr. Rd. 35.583 -83.838 }\end{array}$ & 20-Jul-2004 & R. M. Pyle \\
\hline H. sosybius & $\begin{array}{c}\text { DNA- } \\
\text { ATBI-4110 }\end{array}$ & GU088393* & $\begin{array}{c}\text { TN: Sevier Co., Lyon Spring Rd., } 35.6 \\
-83.4\end{array}$ & 22-May-2005 & Segebarth \\
\hline H. sosybius & $\begin{array}{c}\text { DNA- } \\
\text { ATBI-4109 }\end{array}$ & GU088394* & $\begin{array}{c}\text { TN: Sevier Co., Lyon Spring Rd., } 35.6 \\
-83.4\end{array}$ & 22-May-2005 & Segebarth \\
\hline H. sosybius & NSHer-EUA02 & KF466080* & FL: Gainesville, $29.65-82.32$ & Apr-2009 & K. R. Willmott \\
\hline H. sosybius & NSHer-EUA03 & KF466081* & FL: Gainesville, $29.65-82.32$ & Apr-2009 & K. R. Willmott \\
\hline H. sosybius & NSHer-EUA06 & KF466082* & FL: Gainesville, $29.65-82.32$ & Apr-2009 & K. R. Willmott \\
\hline H. cucullina & NSHer-PE03 & KF466142* & Peru & & C Peña \\
\hline H. gisella & NSHer-J29 & KF466092* & $\begin{array}{l}\text { Brazil: São Paulo, Serra do Japí, Jundiaí, } \\
-23.22-46.92\end{array}$ & 26-Feb-2008 & P. E. C. Peixoto \\
\hline H. atalanta & R10_CA_SP & JN109040* & $\begin{array}{c}\text { Brazil: São Paulo, Ribeirão Cachoeira, } \\
\text { Campinas }\end{array}$ & & \\
\hline H. hermes & NSHer-MG08 & KF466108* & $\begin{array}{c}\text { Brazil: Minas Gerais, Serra do Cipó, } \\
\text { Jaboticatubas, }-18.20-43.50\end{array}$ & Dec-2005 & A. R. M. Silva \\
\hline H. maimoune & NSHer-CO04 & KF466021* & $\begin{array}{c}\text { Colombia, Meta, Bosque Bavaria, } 4.18 \\
-73.65\end{array}$ & 8-Oct-2006 & M. A. Marín \\
\hline H. pimpla & CP04-10 & GU205843* & Peru: Quebrada Siete Jeringas & & \\
\hline H. harmonia & СР06-93 & GU205842* & Peru: Quebrada Siete Jeringas & & \\
\hline H. fallax & NSHer-J17 & KF466089* & \begin{tabular}{|c|} 
Brazil: Sáo Paulo, Serra do Japí, Jundiaí, \\
$-23.22-46.92$ \\
\end{tabular} & 26-Feb-2008 & P. E. C. Peixoto \\
\hline Megisto cymela & $\begin{array}{c}\text { DNA- } \\
\text { ATBI-4114 }\end{array}$ & GU088434* & $\begin{aligned} \text { TN: Sevier Co., Lyon Spring Rd., } 35.6 \\
\\
-83.4\end{aligned}$ & 22-May-2005 & Segebarth \\
\hline H. intricata? & DNA96-016 & AY508548* & Costa Rica: Puntarenas Province & & \\
\hline
\end{tabular}

Abbreviations: SP State Park; L. Lake; Cr Creek tr. trail; nr. near; Co. County; NF National Forest; SF State Forest Rd. Road

* after the species name indicates primary type specimen, ${ }^{* *}$ is Hermeuptychia hermes kappeli holotype

* after the GenBank number indicates that it was retrieved from GenBank, all other sequences were determined by us in this study

Only DNA ID tags were obtained for the oldest specimens and their dates are shown in bold font.

\section{Results and discussion}

Taxonomic status of various Hermeuptychia populations in Texas has been puzzling (Miller and Brown 1981, Pelham 2008). Some authors treated them as conspecific with eastern USA populations, either under the name H. sosybius (Opler and Malikul 1992, Allen 1997, Glassberg et al. 2000, Opler and Warren 2002, Glassberg 2007) or H. hermes (Howe 1975, Opler and Krizek 1984, Scott 1986, Neck 1996). Others apparently assigned more southern populations to $H$. hermes, reserving the name $H$. sosybius for eastern butterflies (Miller and Brown 1981, brief comment in Neck 1996, Pelham 2008, Warren et al. 2013).

As a part of a barcoding exercise to shed some light on taxonomy of Hermeuptychia, we obtained DNA sequences from several samples across Texas. The results were not as expected. In fact, populations from extreme south Texas with the small 
eyespots phenotype characteristic of $H$. hermes revealed barcodes more similar to those across eastern US. Genitalic examinations showed that even specimens from Tamaulipas and San Luis Potosí, Mexico possessed characters of morphogroup 4 (i.e. the one that includes H. sosybius) from Seraphim et al. (2014).

However, much to our surprise, several specimens from southeast (but not southernmost) Texas, namely from the Brazos Bend State Park in Fort Bend County near Houston, possessed barcodes $3.5 \%$ different from those of all other USA populations and, as found by BLAST (Altschul et al. 1990), more than 2\% different from all other available sequences (except one, discussed below) in GenBank (Benson et al. 2013). Both males and females were in the sample with the unusual barcodes.

Suspecting DNA introgression, similar to that reported by Zakharov et al. (2009), or some yet unexplained irregularities with barcodes, we critically inspected genitalia of these butterflies. Even more surprisingly, both male and female genitalia of the specimens with unusual barcodes differed profoundly from those with classic morphogroup 4 (suggested $H$. sosybius) barcodes, and male genitalia were more similar to morphogroups 5, 6 and possibly 7 of Seraphim et al. (2014), differing in certain details from all of them. The morphogroups 5 and 6 included specimens from Peru and south Brazil and were associated with the names H. cucullina (Weymer, 1911) (type locality: Bolivia) and H. gisella (Hayward, 1957), reinstated status (type locality: Bolivia) per data provided by Seraphim et al. (2014). Morphogroup 7 referred to an unnamed phenotype from South Brazil.

Apparently, in Fort Bend County, Texas there exist two sympatric and synchronic Hermeuptychia species (collected on the same day at exactly the same spot!), one from morphogroup 4 and the other one more similar to morphogroups 5, $6 \& 7$. Interestingly, a possible closest named relative of this second species is either $H$. gisella or $H$. cucullina, documented from Bolivia and central to southeastern Brazil. The situation might be analogous to another butterfly recently described from the US, Strymon solitario Grishin \& Durden, 2012, whose possible sibling is Strymon jacqueline Nicolay \& Robbins, 2005 from Peru (Grishin and Durden 2012).

\section{Historical investigations into Papilio sosybius Fabricius, 1793}

The two Hermeuptychia species from east Texas are markedly different in genitalia of both sexes and in DNA barcodes. However, upon close inspection of wing patterns, we failed to find strong diagnostic differences that would hold against individual variation. Searching for additional specimens revealed the presence of both species across the eastern US from Texas to Florida and South Carolina, but didn't reveal obvious wing pattern differences either. This posed a problem with the taxonomic identity of these two species, as it was uncertain which one, if any, is H. sosybius described by Fabricius (1793: 219). In his brief description, Fabricius referenced unpublished drawings ("Icones") by William Jones (Vane-Wright 2010): “Jon. fig. pict. 6. tab. 52. fig. 2." and Drury specimens, but did not state the locality these specimens came from (Figs 


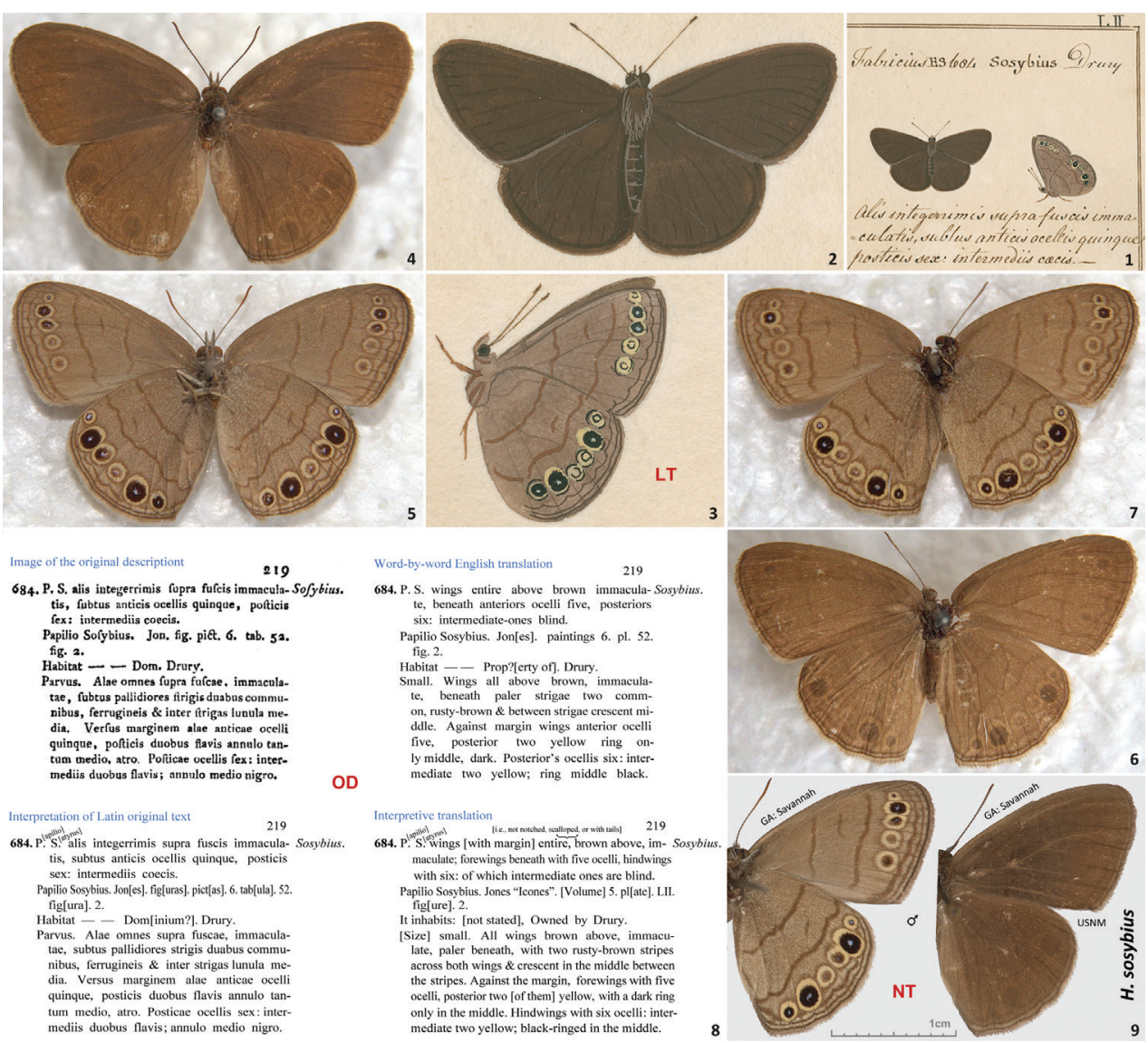

Figures I-9. Historical illustrations and specimens of H. sosybius, its original description, and neotype. I-3 Illustration of $H$. sosybius syntype(s) by William Jones [1745-1818] from an unpublished book called the "Icones" (Vane-Wright 2010), currently in Oxford University Museum of Natural History, UK (Smith 1986). I shows the upper right quadrant of the plate LII from Volume $5 \mathbf{2 , 3}$ are magnified cropped images off this plate showing dorsal and ventral aspects, respectively; ventral image (3) is rotated clockwise for the ease of comparison with specimens. The specimen with ventral side illustrated ( $\mathbf{3}$ and on the right in I) is designated as the lectotype herein and is apparently lost 4-7 Two possible syntypes of $H$. sosybius from the Macleay collection (Macleay Museum, The University of Sydney, Australia). Neither specimen bears any labels $\mathbf{4 , 6}$ show dorsal aspect and $\mathbf{5 , 7}$ show ventral aspect 8 Original description of $H$. sosybius and its translations. Note that the Jones illustrations of $H$. sosybius are currently bound within Volume 5, and not 6 as per description 9 Neotype of $H$. sosybius (designated herein, also see Figs 10-11, genitalia Fig. 62p, DNA barcode tree Fig. 66b), in USNM collection, from USA: Georgia: Chatham Co., Savannah, 28-Jul-1958, leg. G. B. Small, genitalia NVG13110261, DNA voucher 13386A07, GenBank accession for mitochondrial DNA COI barcode KJ025561. Scale bar refers to $\mathbf{9}$ only, other images are scaled approximately. Images $\mathbf{1}-\mathbf{3}$ are copyright of Oxford University Museum of Natural History, UK (used with permission), and images 4-7 are copyright of Macleay Museum, The University of Sydney, Australia and are photographed by Robert Blackburn (used with permission). 
$1-3,8)$. The specimens used by Jones to sketch from and those in the Drury collection (the same specimens?) are H. sosybius syntypes. With the help of Kathleen Santry (Head of Archival Collections), we obtained high resolution digital images of the H. sosybius drawing by Jones from the Hope Library, Oxford University Museum of Natural History (Oxford, UK). The images show a dorsal side of a specimen on the left, which is uniformly dark-brown; and a ventral side of a specimen on the right (Figs 1-3). Consistent with the Fabricius description (Fig. 8), the ventral surface of wings is palerbrown, with darker brown submedial, postmedial, sinuous submarginal and marginal lines across both wings and end-of-cell dark-brown dash on each wing. Submarginal eyespots are large (compared to $H$. hermes): 5 on the forewing, the $2^{\text {nd }}$ and $3^{\text {rd }}$ from the costa are larger, black-ringed and pupiled; 6 on the hindwing, the $2^{\text {nd }}, 5^{\text {th }}$ and $6^{\text {th }}$ from the costa are larger, black-ringed and pupilled, $2^{\text {nd }}$ and $5^{\text {th }}$ being the largest. Generally, this wing pattern is consistent with both Hermeuptychia species from southeast Texas.

We have taken the following steps to trace the type specimens of $H$. sosybius. First, we studied relevant publications. For instance, Zimsen (1964: 561) specifies for "Papilio Sosybius": "». . . Dom. Drury« - " with no specimen location mention after the dash. In contrast, for "Papilio Hermes", Zimsen (1964: 514) lists "»in Brasilia Mus. Banks", ... - London 1 specimen.” Indeed, there is presently a specimen presumed to be $H$. hermes type in Banks collection in BMNH (see images in Warren et al. 2013). Miller and Brown (1981: 191) state "Type lost, a Drury specimen." Pelham (2008: 404) echoes: "Type(s) probably lost."

Second, we consulted knowledgeable historians and scholars of Lepidoptera. John V. Calhoun kindly provided the following information: Drury's collection was sold at auctions and the catalogs of sales did not list specimens of H. sosybius. However, species names for many sold specimens were not given. It is possible that the types of $H$. sosybius were acquired by Macleay and are in the Macleay Museum (Sydney, Australia). However, even if $H$. sosybius specimens could be found in the Macleay collection, it will be nearly impossible to figure out which (if any) served as types. Gerardo Lamas (pers. comm.) was not able to trace $H$. sosybius syntypes in his comprehensive search for the primary type specimens of all Neotropical butterflies, and expressed an opinion that it would be very difficult to support the status of any found specimens as syntypes.

Nevertheless, as a third step, we contacted the Macleay Museum staff with a request to search for specimens similar to those illustrated by Jones in the Macleay collection. After extensive search of the Macleay holdings (housed in two places), Robert Blackburn, armed with the Jones illustrations and photographs of H. sosybius specimens, was able to find four Hermeuptychia specimens of potential interest. According to Mr. Blackburn (pers. comm.), "the history of these 4 is hard [to determine] due to the absolute lack of labels. Much of the material in these drawers came from a mixture of sources, between William Sharp Macleay's trading network of entomologists and Alexander Macleay's purchases at auctions. I think that butterflies like these would be most likely to be Alexander Macleay purchases, and probably came through the purchase of Dru Drury's collections at auction. I think it's absolutely possible that they are 1780 's specimens, maybe even through John Abbot, as many of the other butterflies 
in these drawers are labelled 'Georgia'." Two of these (Figs 4-7) would be identifiable as $H$. sosybius by facies. Unfortunately, neither specimen bears any labels and it will be very difficult to find supporting evidence that these are indeed syntypes. Even if these specimens are from the Drury collection, since Drury exchanged material, it is impossible to know that these are the original specimens, or the ones acquired after the $H$. sosybius description.

Next, we compared these specimens with the Jones illustrations. The wing pattern and shape of the specimen with abdomen intact (female, Figs 6-7) do not agree closely with the Jones illustrations (Figs 1-3). Most notably, Jones's illustration of the ventral aspect (Fig. 3) shows two forewing eyespots with strongly developed black rings (near the apex, $2^{\text {nd }}$ and $3^{\text {rd }}$ from the costa), and the specimen has only one $\left(2^{\text {nd }}\right.$ from the costa, the $3^{\text {rd }}$ eyespot entirely lacks black and is more similar to the two posterior eyespots, Fig. 7). The postmedial dark line on ventral hindwing is shaped differently. e.g., it is directed basad near costa in the illustration and is directed distad in the specimen. Other differences in details of placement and shape of eyespots and dark lines are equally obvious, and it is not likely that this specimen was the model for the Jones illustration.

The specimen lacking the abdomen (Figs 4-5) is more similar to the specimen(s) illustrated by Jones, i.e. both $2^{\text {nd }}$ and $3^{\text {rd }}$ eyespots on the forewing are black-ringed and the postmedial hindwing line (slightly) bends basad at costa. However, it seems to be mounted differently than the Jones's dorsal image shows, i.e. the hindwings that are lowered on the Jones image and touch each other with inner margins, are widely apart in the specimen (Fig. 4). Ventral patterns (in case Jones image Fig. 3 depicts a different specimen from that shown on dorsal image Fig. 2) also differ in detail. In particular, the $3^{\text {rd }}$ hindwing eyespot from the costa lacks black and is more similar to the $4^{\text {th }}$ from costa eyespot in the illustration, but is clearly black-ringed and larger than the $4^{\text {th }}$ eyespot in the specimen (Fig. 5). The submedial and postmedial dark lines on both wings are farther apart in the illustration than in the specimen. The postmedial dark line is strongly bent, directed basad and reaches the hindwing inner margin at an angle in the illustration (more similar to the specimen illustrated in Fig. 47), but is almost perpendicular to the inner margin near the tornus in the specimen. In our opinion, it is not very likely that these obvious pattern differences are caused by inaccuracy of the Jones illustration, in part because we see Hermeuptychia specimens (e.g. Fig. 47) that are more similar in such patterns to the Jones illustration than the specimen in Fig. 5. We see that Hermeuptychia specimens with the characters illustrated by Jones exist, and it seems more likely that their characters were illustrated, rather that invented by Jones. Therefore, we conclude that neither of the specimens from the Macleay collection is the one illustrated by Jones. John V. Calhoun who has vast experience dealing with the analysis of historical illustrations agrees with this opinion (pers. comm.).

To stabilize nomenclature, similarly to Calhoun (2006), we designate the specimen with ventral aspect illustrated by Jones in Volume 5, plate LII (second species illustrated on this plate), topmost image on the right (reproduced here as Fig. 3) in his unpublished manuscript known as "Icones" (Vane-Wright 2010) and referred to as "Jon. fig. 
pict. 6. tab. 52. fig. 2." by Fabricius (1793) in his original description (Fig. 8) as the lectotype of Papilio sosybius Fabricius, 1793. It is possible that the Jones illustration may be a composite, amalgamated image of several specimens. If that was the case, the lectotype is the specimen that contributed the most to the illustration. I.e., of all specimens used as models for this possibly composite illustration, the largest number of characters depicted are from the lectotype. As discussed above, our search for this specimen was unsuccessful, and the lectotype is most likely lost. Because we were not able to find definitive wing pattern characters to differentiate between the two eastern US Hermeuptychia species (one of which is $H$. sosybius and the other one is not), and the Fabricius description (1793, Fig. 8) augmented with Jones illustration of the lectotype (Fig. 3) is generally consistent with both species, we proceeded with the neotype designation.

\section{Neotype designation for Papilio sosybius Fabricius, 1793}

We believe that there is an exceptional need for the neotype to clarify the taxonomic identity of H. sosybius and to define which one of the two USA Hermeuptychia species this name refers to. We hypothesize that it is more likely that the species from morphogroup 4 - i.e. H. sosybius as defined by Seraphim et al. (2014: Table 1 to list its male genitalia characters), characters detailed below - that is widely distributed across eastern US and is more common in collections, is the species that Fabricius named "Papilio Sosybius". For instance, inspection of Hermeuptychia holdings in the USNM collection from 13 US states across its distribution range (MD, VA, SC, GA, TN, AR, AL, KY, MS, LA, TX \& FL) revealed that one species outnumbered the other one more than 20 to 1 (169 vs. 8 specimens). The characters seen in specimens of this entity that is significantly more prevalent in collections are consistent with the original description of H. sosybius and Jones illustration of the lectotype. Most importantly, the Jones ventral drawing (Fig. 3) shows: 1) a rather straight postmedial brown line on the forewing towards the costa; 2) postmedial brown line on hindwing bulges basad near the costa and 3) it bulges distad somewhat anterior or at the level of the vein $M_{3}$ (should be between large and small eyespots in typical specimens of the more common species, and between two middle small eyespots, closer to the posterior small eyespot, in the rarely collected species). These three characters (indicated in Fig. 68, first image from the left below the line, voucher NVG-1542) are typical of morphogroup 4 specimens. However, the third character (the bulge anterior or posterior of vein $M_{3}$ ) is somewhat inconclusive from the Jones drawing (Fig. 3) and could possibly be interpreted either way, creating uncertainty with the lectotype identification from the Jones illustration.

In most specimens of eastern US species from a different morphogroup (5, 6, or 7), the forewing postmedial brown line bends basad from vein $M_{1}$ towards the costa, the hindwing postmedial brown line is more straight near the costa, and it bulges distad around vein $\mathrm{M}_{3}$ (between the two small eyespots in the middle, closer to the posterior eyespot). While the sample of 21 specimens is too small to evaluate the reliability of the wing pattern characters and even this sample already shows variation in 
these characters (e.g. in some specimens the forewing line is straight towards the costa), morphogroup 4 species seems to be more consistent with Jones's lectotype drawing in patterns. Combining this albeit rather weak wing pattern evidence with the 20 to 1 ratio of morphogroup 4 specimens found in collections, its possibly wider distribution across eastern US, and the usage of the name "sosybius" in publications to denote this phenotype and DNA barcode (e.g. Seraphim et al. 2014), we conclude that morphogroup 4 species better represents $H$. sosybius of Fabricius, and look for a neotype specimen of this species.

While this species cannot be confidently identified by wing patterns at the moment, it can be differentiated from other Hermeuptychia species by the following combination of male genitalia characters (Figs 60a, d, g, j, 61c, 62o-z2): (1) comparatively large, more gracile and weaker sclerotized (paler) genital capsule (Fig. 60a); (2) medially wider uncus with more prominently convex sides in dorsal (or ventral) view, uncus appears truncated at the apex in dorsal (or ventral) view, but the width of uncus at the apex is generally less than $2 / 3$ of the width of uncus at the narrowest point near the base (Figs 60a, d, 61c); (3) uncus dorsally flatter towards the apex, but convex in lateral view towards the base and with a prominent, thin, membranous carina in basal half (Fig. 60j); (4) valvae elongated, with a saccular lobe, cucullus more gracile, narrower and longer, it projects for close to half of its length farther than the distal end of gnathos (lateral view, Fig. $60 \mathrm{~g}, \mathrm{j}$ ); (5) cucullus narrow at the apex, usually with three to five (mostly four) prominent apical teeth (Fig. 60g, j); (6) interior surface of cucullus ventrally without a prominent bulge, best seen in ventral view (Fig. 60d); (7) aedeagus is more gracile, narrower and longer, especially near the distal end, evenly curved or bent distad the middle (Fig. 60d, g, j); (8) longer than wide phallobase (Fig. 60g, j); (9) larger and wider saccus, but shorter than $2 / 3$ of valva length (Fig. 60d). Further analyses and comparisons of genitalia characters between Hermeuptychia species are given in Table 1 of Seraphim et al. (2014). In addition, specimens from morphogroup 4 of Seraphim et al. (2014) clustered as molecular group G in the DNA barcode tree. All 40 DNA barcodes we obtained for specimens of the species that we are selecting to represent $H$. sosybius, closely clustered together with the sequences of group $\mathrm{G}$ in our trees as well (Fig. 66b).

From the Jones drawing, it is not possible to unambiguously determine the sex of the illustrated specimens because Hermeuptychia are not prominently dimorphic sexually, although the darker color of the specimen shown in dorsal view and wing shape on both illustrations is more consistent with a male. We decided to choose a male specimen as the neotype because male genitalia have been used more widely in Hermeuptychia taxonomy, were illustrated for the majority of known species by Forster (1964) and extensively analyzed by Seraphim et al. (2014).

The locality of $H$. sosybius types was not stated in the original description and currently remains unknown. However, we could attempt to deduce it by comparative analysis of wing patterns on Jones's drawings. Large eyespots on both wings, some mostly black and pupilled with pale blue are distinctive. Because the size of eyespots is highly variable in Hermeuptychia, it is conceivable that the Drury's specimens origi- 
nated in Central or even South America. However, due to very strong development of eyespots and characteristic shape of rusty-brown lines ventrally on both wings, Jones's drawings are more likely to depict eastern USA Hermeuptychia. Most importantly, the name "sosybius" has been applied to these USA populations historically, and in the interest of stability it is best to secure this name for these populations. If the H. sosybius types were collected in the USA, it is most likely that Drury obtained them from John Abbot and they originated in the eastern coastal US, possibly in Georgia or Virginia (John V. Calhoun, pers. comm.). Populations of the morphogroup 4 species are continuous and widely distributed in east US (Opler et al. 2013), and they show essentially identical DNA barcode sequences from North Carolina to south Texas (Fig. 66b). Genitalia of inspected specimen do not reveal notable differences across the range either. Recently, Robbins and Lamas (2006) designated a neotype of Calycopis cecrops (Fabricius, 1793), a species described by Fabricius in the same publication with $H$. sosybius and under similar circumstances (i.e., Jones illustrations) from "Indiis", later proposed to be "one of the states along the eastern coast of the United States between Virginia and Georgia, and probably the latter" by Field (1967). Robbins and Lamas (2006) have chosen the neotype to be from USA: Georgia: Chatham Co., Savannah. We could not have done better, and simply follow their example.

A male specimen (Figs 9-11, genitalia Fig. 62p) bearing three rectangular labels: yellowing white, handprinted on one side - || SAVANNAH, GA. | VII-28-58 ||, grayish, handwritten on the other side - || Coll | G B Small ||; white printed - || DNA sample ID: | 11-BOA-13386A07 | c/o Nick V. Grishin ||; white printed - || NVG131102$61 \|$; and a plastic glycerin-filled vial with genitalia on the same pin with the specimen, is hereby designated as the neotype of Papilio sosybius Fabricius, 1793. Upon this publication, red printed label || NEOTYPE के | Papilio sosybius | Fabricius, 1793 | designated by Grishin $\|$ will be added. Forewing length of the neotype is $15.5 \mathrm{~mm}$, and this specimen can be recognized by a unique pattern of minor damage to scale cover on wings above, i.e. a longitudinal scratch in the distal half of the left forewing discal cell and a scratch across the discal area of both right wings (Fig. 10). Prior to genitalia dissection, abdomen of the neotype was used to extract total genomic DNA as described in Materials and methods section. The neotype wing pattern mostly agrees with the original description and is similar to Jones illustrations, and the choice of the species is consistent with the usage of this name. The original type locality is not specified in the description (Fig. 8), and the new type locality of H. sosybius according to ICZN Article 76.3 (ICZN 1999) is USA: Georgia: Chatham Co., Savannah. The neotype is in the National Museum of Natural History, Smithsonian Institution, Washington, DC (USNM). It is our pleasure to select this excellent specimen collected by Gordon B. Small, one of the most knowledgeable and finest collectors of American, and in particular Panamanian, butterflies (Nicolay 1989), who "knew more about butterflies than any person" (DeVries 1989) and whose exquisite and comprehensive collection of over 50,000 masterfully prepared specimens, rich in rare and undescribed species, is in USNM for future generations to study.

Barcode sequence of the neotype: Genbank accession KJ025561, 658 base pairs: 


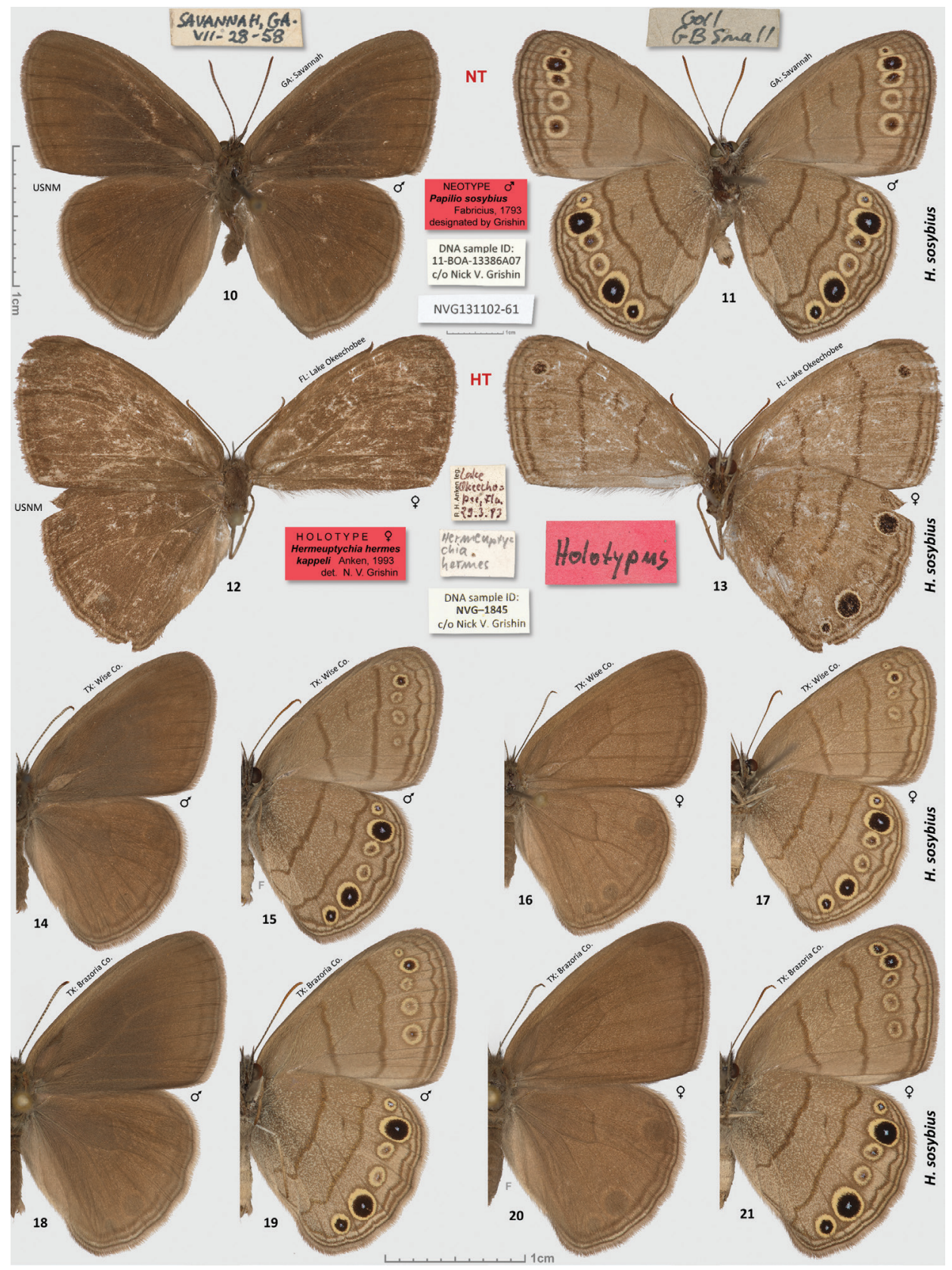

Figures I0-2 I. Hermeuptychia sosybius. I0-II neotype designated herein and I 2-I3 holotype of H. hermes kappeli, data in text I4-I5 0 USA: Texas, Wise Co., LBJ National Grassland, ex ovum, eclosed 3-Aug-1998, leg. N. V. Grishin 16-17 9 ibid, 10-Aug-1998 18-19 đ USA: Texas, Brazoria Co., Bar-X Ranch, Rd. 971N, ex ovum, eclosed 18-Apr-2000, leg. N. V. Grishin 20-2I 9 ibid, 21Apr-2000. Dorsal/ventral surfaces are in even/odd-numbered figures. Labels are shown for primary types in-line with the specimens and are reduced 2.5-fold compared to specimens as indicated by a smaller scale bar. "F" specifies mirror image (left-right inverted). 
AACTTTATATTTTATTTTTGGTATTTGAGCAGGAATAATTGGAACATCATTAAGTTTAATTATCCGAATAGAATTAGGTAACCCAGGATTTTTAATTGGAGATGACCAAATTTATAATACTATTGTTACAGCTCATGCTTTTATTATAATTTTTTTTATAGTAATACCTATTATAATTGGAGGATTTGGTAATTGACTTATTCCTTTAATATTAGGAGCTCCTGATATAGCTTTTCCGCGTATAAATAATATAAGATTTTGATTATTACCTCCATCTTTAATTTTATTAATTTCTAGCAGTATTGTAGAAAATGGAAGTGGAACAGGATGAACTGTTTACCCCCCTCTTTCATCTAATATTGCTCATAGAGGTTCTTCAGTAGATTTAGCAATTTTTTCTCTTCATTTAGCTGGAATTTCATCAATTTTAGGAGCTATTAATTTTATTACAACAATTATTAATATACGAATTAATAATATATCTTATGATCAAATACCTTTATTTATTTGAGCTGTAGGAATTACTGCTCTTCTTTTACTTCTCTCATTACCTGTTTTAGCAGGAGCTATTACCATACTTCTTACTGATCGAAATTTAAATACATCATTTTTTGATCCT GCAGGAGGAGGAGATCCTATTTTATATCAACATTTATTT

We believe that our designation of the neotype completely satisfies qualifying conditions of the ICZN Article 75.3 (ICZN 1999). I.e., the exceptional need for the neotype arose due to our discovery that more than one Hermeuptychia species was present in eastern USA, and neither the original description, nor the only available illustration of Papilio sosybius Fabricius, 1793 lectotype was sufficient to determine which species, if any, was $H$. sosybius. The neotype was designated to clarify the taxonomic identity of H. sosybius, i.e., to define which one of the two eastern US Hermeuptychia species (than cannot be confidently told apart by the wing patterns) was $H$. sosybius, and to clarify the type locality of $H$. sosybius, which was not stated in the original description (Art. 75.3.1). H. sosybius was differentiated from other Hermeuptychia species by its DNA barcode given above that placed it in a molecular group $\mathrm{G}$ of Hermeuptychia species per Seraphim et al. (2014), and by its attribution to the morphogroup 4 by Seraphim et al. (2014), who listed its diagnostic male genitalia characters (Seraphim et al. 2014: Table 1); these characters were elaborated upon and illustrated in this study, e.g., Fig. 60a, d, g, j (Art. 75.3.2). The neotype specimen could be recognized by its labels and appearance as described above and was illustrated in Figs 9-11 (Art. 75.3.3). The reasons to believe that the $H$. sosybius lectotype was lost and the steps we took to trace it were detailed above under the heading "Historical investigations into Papilio sosybius Fabricius, 1793" (Art. 75.3.4). We presented the evidence that the neotype was consistent with prior knowledge about $H$. sosybius and was in full agreement with the traditional and current usage of this name (Art. 75.3.5). The neotype specimen came from the general geographic area of hypothesized origin of the lectotype (Art. 75.3.6). Finally, we stated that the neotype is in USNM collection (Art. 75.3.7).

The name "Hermeuptychia hermes kappeli" suggested by Anken (1993), type locality "Lake Okeechobee (Nord), Florida, U.S.A." was regarded as a junior subjective synonym of $H$. sosybius by Calhoun (1997), Lamas (2004) and Pelham (2008). The $H$. h. kappeli holotype (Table 1, Figs 12-13, USA: Florida: N of Lake Okeechobee, 29Mar-1983, leg. R. H. Anken, to be deposited in USNM) kindly mailed to us by Dr. R. H. Anken lacks the abdomen, rendering genitalic examination impossible. We ob- 
tained a barcode sequence from its legs (Genbank accession KJ025562) to compare $H$. h. kappeli with other Hermeuptychia. The sequence was $100 \%$ identical with that of $H$. sosybius neotype (Fig. 66b) and was more than $3.4 \%$ different from either the new species, or $H$. hermes. Wing patterns (see discussion below) of the $H$. h. kappeli holotype were also more consistent with $H$. sosybius than with the new species to be described below. Therefore, $H$. h. kappeli is either a subspecies of $H$. sosybius, or its subjective junior synonym as previously proposed (Calhoun 1997, Lamas 2004, Pelham 2008). Because DNA barcodes may not vary with subspecies, and we did not study sufficient material from near the type localities of both taxa, we cannot comment on the validity of H. s. kappeli as a subspecies and adopt the latest treatment (Pelham 2008). However, several butterflies in Florida tend to be regarded as distinct subspecies from nominal taxa with type localities in Georgia or South Carolina (Pelham 2008, Warren et al. 2013). Therefore, a more detailed comparative analysis of wing patterns in $H$. sosybius populations might be desirable.

No other names have been proposed for North and Central American Hermeuptychia. Now, after the clarification of the morphogroup 4 species identity by the $H$. sosybius neotype designation and conclusion that $H$. h. kappeli is either a subspecies or synonym of $H$. sosybius, we can proceed with the description of a different morphogroup $(5,6$, or 7$)$ species from southeast Texas.

\section{Hermeuptychia intricata Grishin, sp. n.} http://zoobank.org/A89BD0A9-9CE9-4DC7-9EFD-42F77A34B2DD http://species-id.net/wiki/Hermeuptychia_intricata Figs 22-35, 40-43, 60c, f, i, 1, 61a, 62n, 64i-p, 65 part, 66 part, 67 part, 68 part

Description. Male ( $\mathrm{n}=14$, Figs 22-23, 28-29, 32, 34-35, 40-43, 68 part) - holotype forewing length $=16.5 \mathrm{~mm}$. Forewing triangular, rounded at apex and tornus, costal and outer margins convex, inner margin almost straight, mildly concave mediad, two discal cell veins bulged at bases, vein $2 \mathrm{~A}$ thickened basad. Hindwing rounded, almost circular. Wings dorsally dark-brown with sparse olive-beige overscaling and two darker-brown terminal lines. Wings ventrally pale-brown, paler towards inner margin of forewing, with extensive beige overscaling, particularly along veins in distal part in some specimens; submedial and postmedial dark-brown lines and dark-brown end-of-cell streak (smaller on hindwing) between them; forewing postmedial line bent basad near costa in many specimens; hindwing postmedial line almost straight near costa, rarely convex basad and typically convex distad posterior of $\mathrm{M}_{3}$ (between the two small eyespots in the middle, closer to posterior eyespot); two terminal dark-brown evenly curved marginal lines, dark-brown sinuous submarginal line, and row of submarginal eyespots basad of the sinuous line and posteriad of outer discal line, largest eyespots black-centered and pupiled with pale-blue scales: on forewing, largest eyespot in cell $M_{1}-M_{2}$, eyespot in cell $\mathrm{R}_{5}-\mathrm{M}_{1}$ black-centered in some specimens; on hindwing, largest eyespots in cells $\mathrm{Cu}_{1}-$ $\mathrm{Cu}_{2}$ and $\mathrm{M}_{1}-\mathrm{M}_{2}$, a smaller one in cell $\mathrm{Cu}_{2}-1 \mathrm{~A}+2 \mathrm{~A}$, even smaller, but still black-centered 


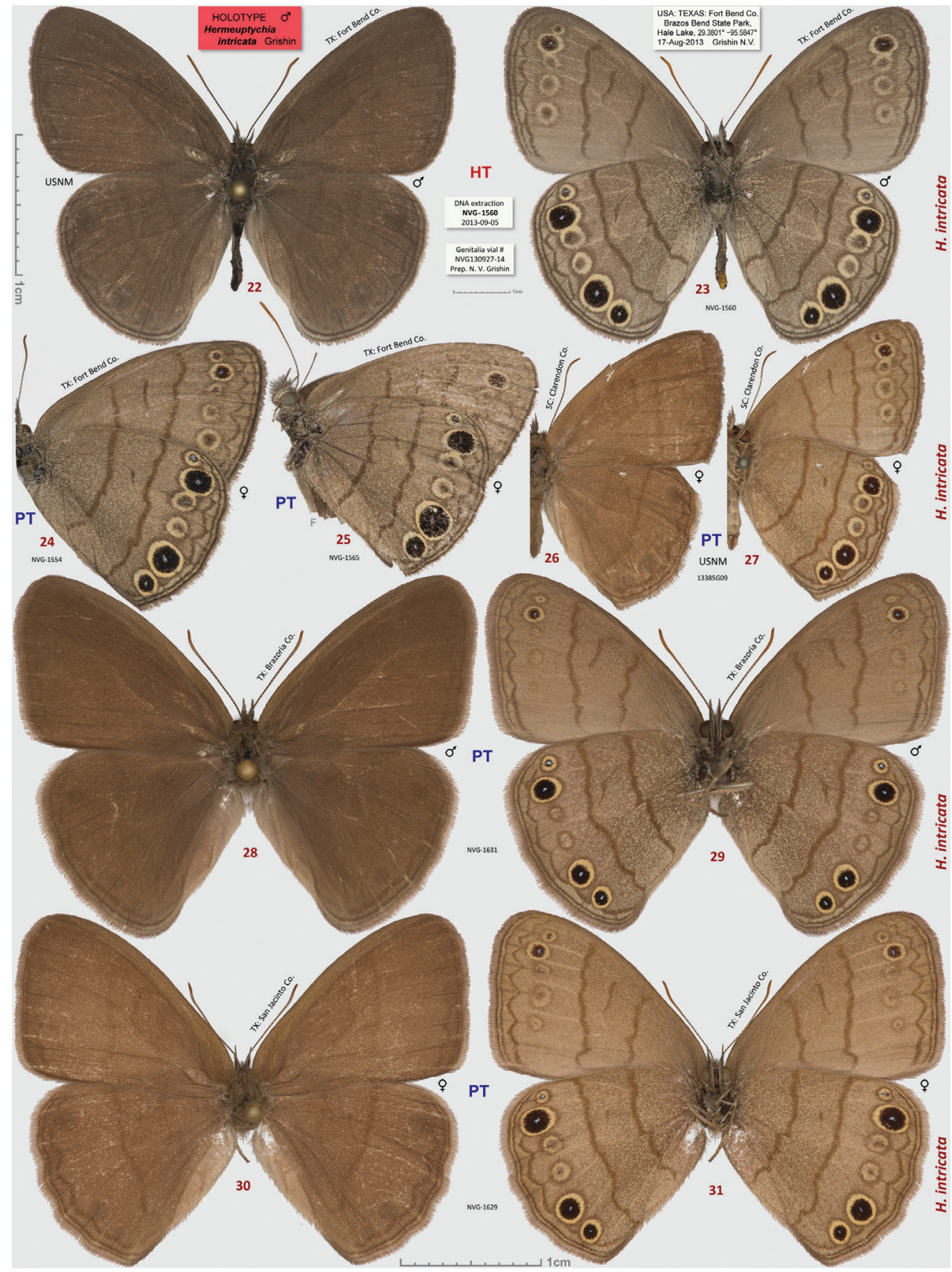

Figures 22-31. Hermeuptychia intricata. 22-23 holotype, others are paratypes, data in text and Table 1. Sexes and DNA voucher codes are: $24+$ NVG-1554 25 + NVG-1565 26-27 + 13385G09 28-29 NVG-1631 30-3I $\uparrow$ NVG-1629. Dorsal/ventral surfaces are in even/odd-numbered figures, except 24, which is ventral. Labels are shown for the holotype and are reduced 2.5-fold compared to specimens as indicated by a smaller scale bar. "F" specifies mirror image (left-right inverted). 
and pale-blue pupilled in cell Rs- $\mathrm{M}_{1}$, and two smallest, usually without black, but in some specimens pale-blue pupilled eyespots in cells $\mathrm{M}_{2}-\mathrm{M}_{3}$ and $\mathrm{M}_{3}-\mathrm{Cu}_{1}$. Fringes monochrome, a little paler than the ground color of wings. Head, palpi, thorax and abdomen dark-brown above, paler and mostly beige beneath. Antennae dark-brown above with pale scales at segments, orange-brown at the club, beneath beige basad, orange-brown in distal half. Legs brown with beige scales. Male genitalia ( $\mathrm{n}=14: 12$ dissected, 2 inspected in situ, Figs 60c, f, i, 1, 61a, 62n) - typical for the genus, smaller and darker in color (more sclerotized) than those of $H$. sosybius. Tegumen dome-like, rounded at margins. Uncus leaf-shaped in dorsal view, angled to the sides, roof-like, convex distally but almost flat basally in lateral view, without thin, membranous carina in basal half; apex of uncus pointed, not truncated. Gnathos arms thin, wide apart, divergent, about the same length as uncus. Valvae narrow, elongated with thin cuculli extending past gnathos not farther than a third of their length; cucullus more rounded at apex, usually with a couple of small teeth; cucullus ventrally with inner medial bulge. Saccus about the same length as cucullus, narrow. Aedeagus elongated, almost straight, only slightly and evenly curved, not bent, broader and shorter compared to $H$. sosybius, with a smaller, about as long as wide phallobase. Female ( $\mathrm{n}=8$, Figs 23-27, 30-31, 33, 68 part) - similar to male in facies, with slightly more rounded wings and dorsally paler in color. Female genitalia $(\mathrm{n}=8$, Fig. 64i-p) with antrum darker in color and smaller than that of $H$. sosybius. Ostium bursae ellipsoidal, its ventral margin longer than dorsal margin. Antrum narrower anteriad, almost triangular in ventral view, somewhat kidney-shaped in lateral view, mostly symmetric. Ductus and corpus bursae each in length similar to antrum; corpus bursae with two signa, spines in a signum broad, leaf-shaped, usually shingled in two rows.

Barcode sequence of the holotype. Genbank accession KJ025595, 658 base pairs:

AACTTTATATTTTATTTTTGGTATTTGAGCAGGAATAATTGGTACATCATTAAGTTTAATTATCCGAATAGAATTAGGTAATCCAGGATTTTTAATTGGAGATGACCAAATTTATAATACTATTGTTACAGCTCATGCTTTTATTATAATTTTTTTTATAGTAATACCCATTATAATTGGAGGATTTGGTAATTGACTTGTCCCTTTAATATTAGGAGCTCCTGATATAGCTTTCCCACGTATAAATAATATAAGATTTTGATTATTACCCCCATCTTTAATTTTATTAATTTCTAGTAGTATTGTAGAAAATGGAAGTGGGACAGGATGAACAGTTTACCCCCCCCTCTCATCTAATATTGCTCATAGAGGTTCTTCAGTAGATTTAACAATTTTTTCACTTCATTTAGCTGGAATTTCTTCAATCTTAGGAGCTATTAATTTTATTACAACAATTATTAACATACGAATCAATAATATATCTTATGATCAAATACCTTTATTTATTTGAGCTGTAGGAATTACAGCTCTTCTTTTACTTCTTTCATTACCTGTTTTAGCAGGAGCTATTACTATACTTCTTACTGATCGAAATTTAAATACATCATTTTTTGATCCTGCAGGAGGAGGAGATCCTATTTTATATCAACATTTATTT

In addition to the holotype, barcodes and ID tags were obtained for 19 paratypes (15 full-length barcodes and 4 ID tags, see Table 1, GenBank accessions: KJ025588KJ025607, except KJ025595, which is the holotype). Full length barcodes revealed five haplotypes differing from each other by just 1 to 3 base pairs (less than $0.5 \%$ ). 


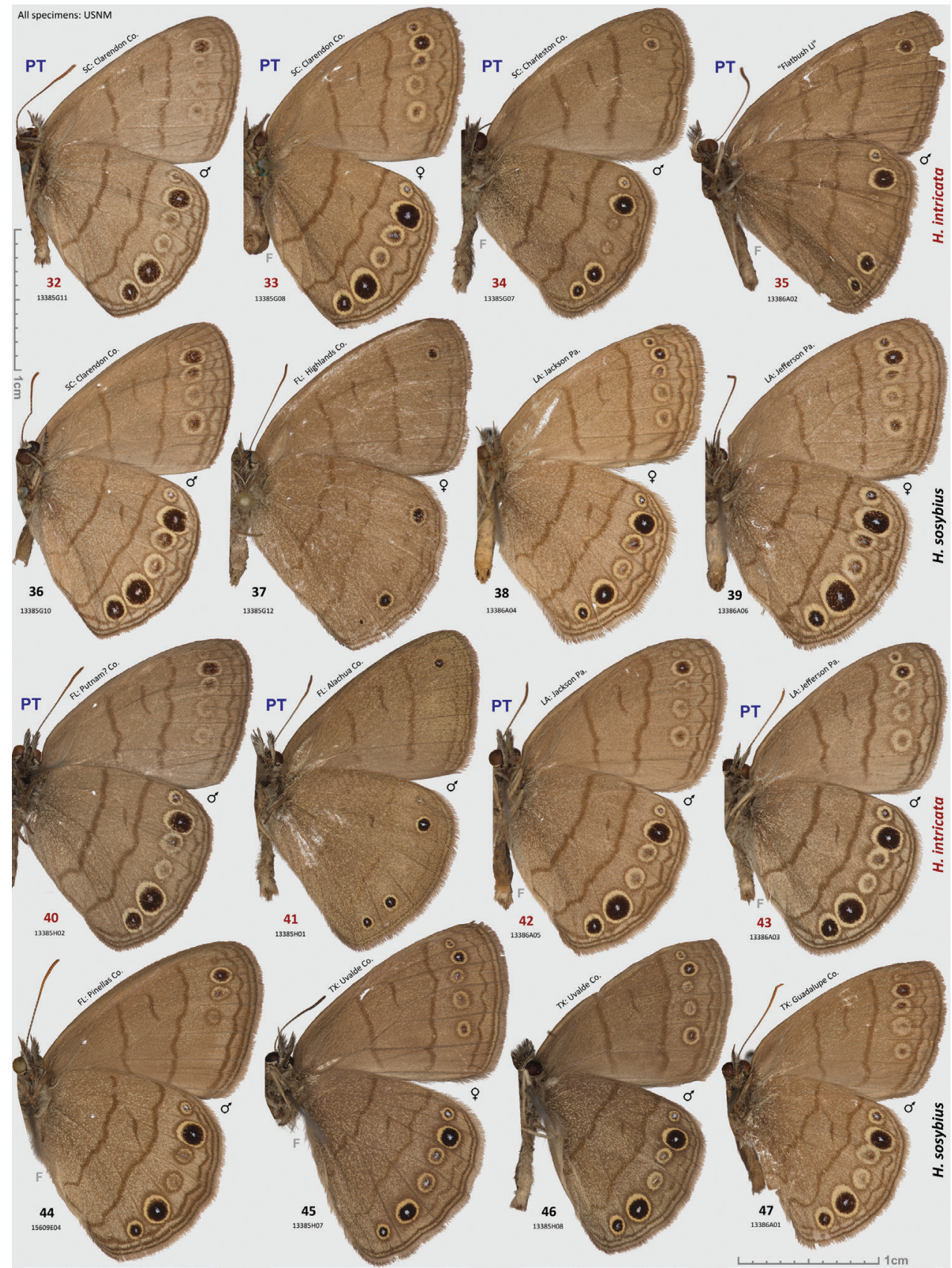

Figures 32-47. $H$. intricata paratypes and $H$. sosybius specimens. 32-35, 40-43 H. intricata 36-39, 44-47 H. sosybius; data in text and Table 1 . Sexes and DNA voucher codes are: 32 13385G11

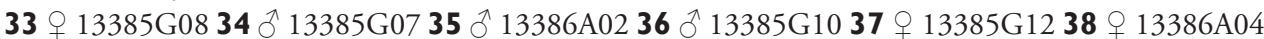

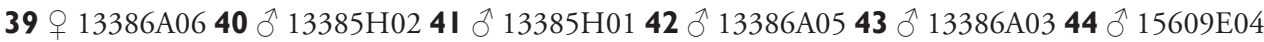
45 ㅇ $13385 \mathrm{H} 0746$ 13385H08 47 13386A01. All specimens are in USNM collection. Ventral wing surfaces are shown. "F" specifies mirror image (left-right inverted). 
The haplotype of the holotype was more frequently observed (Fig. 66b) and other four haplotypes were confined to a single specimen in the sample.

Type material. Holotype: $\widehat{\sigma}$, has the following four rectangular labels: white printed - || USA: TEXAS: Fort Bend Co. | Brazos Bend State Park, | Hale Lake, $29.3801^{\circ}-95.5847^{\circ} \mid 17$-Aug-2013 Grishin N.V. ||; white printed - || DNA extraction | NVG-1560 | 2013-09-05 ||; white printed - || Genitalia vial \# | NVG130927-14 | Prep. N. V. Grishin ||; red printed - || HOLOTYPE ठิ | Hermeuptychia | intricata Grishin ||. The holotype is illustrated in Figs 22-23, 60c, f, i, 1, \& 68 (first image), and the Genbank accession for its DNA COI barcode sequence is KJ025595. Upon publication, the holotype will be deposited in the National Museum of Natural History, Smithsonian

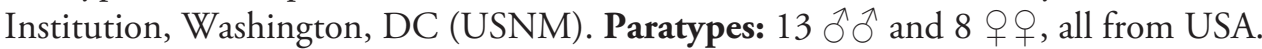

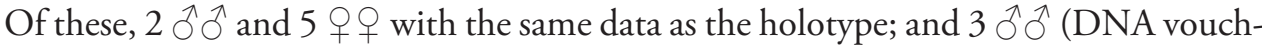
ers: NVG-1541, NVG-1548, \& NVG-1551) from $2.5 \mathrm{~km}$ to the east, i.e. USA: Texas: Fort Bend Co., Brazos Bend State Park, Horseshoe Lake trail, latitude 29²2'54.96", longitude -95³6'41.06", elevation 15 m, 17-Aug-2013, leg. N. V. Grishin. Sexes and GenBank accessions|DNA voucher numbers|genitalia codes (na if not available) for these paratypes (the same format is used below for others) are: 0 KJ025588|NVG-

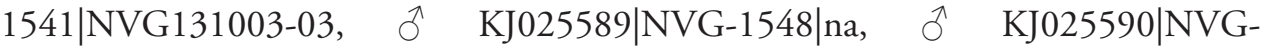
1551|na, क KJ025591|NVG-1554|NVG130927-07, क $\quad$ KJ025592|NVG1555|NVG131003-04, ते KJ025593|NVG-1556|NVG131003-05, q KJ025594|NVG-1558|NVG130927-08, + KJ025596|NVG-1563|NVG130927-11, + KJ025597|NVG-1565|NVG130927-12, q na|na|NVG131003-10. All but one of these paratypes are illustrated in Figs 24, 25, 68 (above the line). 1 त Texas: Brazoria Co., Bar-X Ranch, Rd. 971N, 29.13252 -95.58340, 7 m, 4-Mar-2000, leg. Nick V. Grishin, KJ025599|NVG-1631|NVG131017-08 (Figs 28-29, 62n). 1 † Texas: San Jacinto Co., Sam Houston National Forest, USF217@ Big Creek, 58 m, 12-Apr1998, leg. Nick V. Grishin, KJ025598|NVG-1629|NVG131017-06 (Figs 30-31). 1 đ South Carolina: Charleston Co., McClellanville, Wedge Plantation, 6-Apr-1970, leg. D. C. Ferguson, KJ025600 | 13385G07|NVG131102-38 (Fig. 34). 1 q South Carolina: Clarendon Co., 9-Aug-1898, KJ025604|13385G08|NVG131102-39 (Fig. 33). 1 o ibid., Aug-1910, KJ025605|13385G09|NVG131102-40 (Figs 26-27). 1 đ̃ ibid., Aug-1910, KJ025606|13385G11|NVG131102-42 (Fig. 32). 1 त Florida: "Putnam Co | Shell Bluff Landing", 29-Sep-1985, George Balogh, KJ025602|13385H02|NVG131102-45 (Fig. 40). 1 § Florida: Alachua Co., Gainesville, 12-Mar-1983, leg. Scott W. Gross, KJ025601|13385H01|NVG131102-44 (Fig. 41). 1 ઈ Louisiana: Jefferson Parish, Harahan, 28-Jun-1944, W. D. Field, KJ025603|13386A03|NVG131102-57 (Fig. 43). 1 ते Louisiana: Jackson Parish, Jonesboro, na|13386A05|NVG131102-59 (Fig. 42). 1 స̋ "Flatbush LI" (specimen curated in the USNM among Hermeuptychia from Louisiana), collected prior to 1941, G. P. Engelhardt Coll., KJ025607|13386A02|NVG131102-56 (Fig. 35).

Type locality. USA: Texas: Fort Bend Co., Brazos Bend State Park, near Hale Lake, latitude $29^{\circ} 22^{\prime} 48.27^{\prime \prime}$, longitude $-95^{\circ} 35^{\prime} 05.02^{\prime \prime}$, elevation $16 \mathrm{~m}$. This locality is 
by a wooded, partly open, lowland hiking trail (near and along the park paved road) from a parking lot towards the Big Creek, north of the Hale Lake.

Etymology. The name refers to the difficulty in recognizing this very distinct species and its intricate ventral wing patterns. The name is an adjective.

Distribution. Generally, this is a species of eastern US coastal plains and is currently documented from Texas, Louisiana, Florida, and South Carolina (Fig. 67). It is expected to be more widely distributed in the region and the exact boundaries of the range remain to be investigated. For instance, photographs of live individuals from Alabama: Bibb Co., Blue Girth Creek, 08-VIII-2004 \& 18-VI-2005 by Vitaly Charny (Warren et al. 2013, specimens not collected, excluded from the type series) exhibit characters more consistent with $H$. intricata than with $H$. sosybius (see discussion below). Furthermore, it is difficult to interpret the locality label for the last listed paratype other than "Flatbush Long Island" [New York, Kings Co.]. However, Hermeuptychia has not been recorded that far north-northernmost records are from southern New Jersey and southern Pennsylvania (Opler et al. 2013)-therefore this specimen might have been mislabeled. Nevertheless, searches for this species in the coastal New York/New Jersey area might be interesting to probe its northern distribution limits. An additional specimen (not examined, excluded from the type series) from Costa Rica: Puntarenas Province, GenBank accession AY508548 (Murray and Prowell 2005) has DNA sequence with only 1 bp difference (over 435 base pair C-terminal segment of the barcode) from the USA $H$. intricata barcodes. Unless this sequence is a contamination, it is possible that the Costa Rican specimen is $H$. intricata, which may be ranging southwards at least to Costa Rica. It is apparent, however, that $H$. intricata is either more restricted in distribution and local, or significantly less common than $H$. sosybius, because several dozen available barcode sequences of Hermeuptychia specimens from different parts of the range in east US (NC, TN, FL, LA, OK and TX, see Fig. 66b) clearly group with $H$. sosybius, and a sample of 177 genitalically inspected Hermeuptychia specimens from 13 US states (MD, VA, SC, GA, TN, AR, AL, KY, MS, LA, TX \& FL) in the USNM yielded only $8 \mathrm{H}$. intricata (less than $5 \%$ ). We hope that a timely description of this species within a few months after its initial discovery will stimulate further studies of this interesting cryptic-in-facies butterfly, which, however, can be easily distinguished from its more common congener by genitalia (Figs 60a, c, d, f, g, i, j, 1, 61a, c, 62n-z2 \& 64a-p) and DNA barcodes (Fig. 66). All known H. sosybius records should be scrutinized in search for $H$. intricata.

Diagnosis. In wing pattern, the new species is very similar to $H$. sosybius. We were not able to find solid diagnostic characters for the new species, and only hypothetical field marks could be suggested (see discussion). However, it could be easily identified by many distinctive characters of genitalia.

Males of the new species possess: (1) smaller and more robust and darker genital capsule, even in males with larger body size (Fig. 60c)-genitalia of H. sosybius from various parts of the range are larger and look "wider" and are paler (Fig. 60a); (2) narrower and apically pointed uncus (Fig. 60c, f)-uncus of $H$. sosybius is wider and appears truncated at the apex in dorsal or ventral views (Fig. 60a, d); (3) uncus that 
is more angled to the sides along the dorsal "rim", thus appearing "higher" in lateral view (Fig. 601), but flatter basally due to the lack of prominent carina, vs. a dorsally flatter uncus in distal half, with a well-developed thin, membranous carina in basal half in H. sosybius (Fig. 60j); (4) shorter and stouter cucullus, which projects for less than a third of its length farther than the distal ends of gnathos arms (lateral view, Fig. $60 \mathrm{i}, 1)$-cucullus in $H$. sosybius is more gracile, narrower and longer, it projects for close to half of its length farther than the distal end of gnathos (lateral view, Fig. $60 \mathrm{~g}, \mathrm{j}$ ); (5) cucullus more rounded at the apex, usually with a couple of barely defined, very small apical teeth, vs. three to five (mostly four) larger teeth in H. sosybius; (6) interior surface of cucullus ventrally with a more prominent bulge, best seen in ventral view (Fig. 60f vs. 60d); (7) more stout, thicker and shorter penis, best seen in ventral view (Fig. 60f)-penis is more gracile, narrower and longer, especially near the distal end, in H. sosybius (Fig. 60d); (8) shorter phallobase, which is about as long as wide (Fig. 60i, 1), vs. phallobase that is much longer than wide in $H$. sosybius (Fig. 60g, j); (9) smaller and narrower saccus (Fig. 60f), vs. larger and wider one in H. sosybius (Fig. 60d); (10) more obtuse angle formed by the tegumen and vinculum in lateral view (Fig. 601), vs. typically more acute angle in $H$. sosybius (Fig. 60j).

Females of the new species possess: (I) narrower ostium bursae and smaller, darker antrum (Fig. 64i, j)-ostium bursae and antrum are larger and antrum is paler in color in H. sosybius (Fig. 64a, b); (II) ventral margin of ostium bursae that extends farther back than its dorsal margin (Fig. 64k, l)-dorsal margin extends posterior of ventral margin in $H$. sosybius (Fig. 64a, b); (III) antrum that is narrower anteriad, almost triangular in ventral view and symmetric (Fig. 64k, m), vs. rounder, cup-like, slightly asymmetric to the left antrum in $H$. sosybius (Fig. 64e); (IV) more bent antrum, kidney-shaped in lateral view (Fig. 64n), than that of H. sosybius (Fig. 64j); (V) signa composed of wider, more flattened and rounder spines, mostly in two rows, vs. narrower spines in three to five irregular rows in $H$. sosybius.

Characters (2) and (3) in males (more pointed apex of uncus and uncus more angled to the sides from the central "rim") seem to be the easiest to examine without full dissection by brushing the scales off the abdomen tip, even in dry specimens (Fig. 62a, c). Identification of dry females might be more problematic due to abdomen shriveling, however, in freshly caught individuals, ostium bursae and antrum can be easily exposed by squeezing the abdomen in distal third, and the character (II) becomes observable (relative position of ostium bursae margins). Due to these very significant and easily observed differences in genitalia, identification in the field immediately after capture is expected to be straightforward, however, more work remains to be done to discover diagnostic wing pattern characters.

DNA barcodes, consistently with genitalia, set the new species far apart from sympatric $H$. sosybius, and the difference is about 3.5\%, which is significantly higher than "a clear threshold for intra- and interspecific mean distances around 2\%", as quoted from the recent comprehensive analysis of Hermeuptychia (Seraphim et al. 2014).

While the discovery of this second (and new) Hermeuptychia species in eastern USA was very unexpected to us, the next finding is less surprising, although also interest- 
ing. Our analysis of DNA barcodes of Texas Hermeuptychia revealed that populations from the lower Rio Grande Valley region of Texas (Webb, Zapata, Starr, Hidalgo, and Cameron Counties) form a tight cluster differing by at least $2 \%$ from closely clustered barcodes (divergence average $0.09 \%$, standard deviation $0.19 \%$, maximum below $1 \%$ ) of over $50 \mathrm{H}$. sosybius specimens across its range from North Carolina to Texas (south to Uvalde, Comal, Guadalupe and Brazoria Counties, Figs 66-67). These south Texas (and northeast Mexico) Hermeuptychia populations are phenotypically characterized by smaller and more uniformly sized eyespots and more undulated brown lines. This butterfly has been called " $H$. hermes" in some of the recent literature that advocates the presence of two Hermeuptychia species in the US (Miller and Brown 1981, brief comment in Neck 1996, Pelham 2008, Warren et al. 2013). However, DNA barcodes clearly and confidently group these populations with $H$. sosybius (Fig. 66a, bootstrap support above $80 \%$, about $2 \%$ sequence difference), and $H$. hermes sequences are more than $4 \%$ different from either of these [Fig. 66a and Seraphim et al. (2014)]. According to DNA barcodes, $H$. hermes - type locality Brazil: Rio de Janeiro - is in a different species group and clusters with $H$. maimoune (A. Butler, 1870) rather than with $H$. sosybius (Fig. 66a). Analysis of male genitalia agrees with this conclusion. Indeed, genitalia of south Texas specimens are clearly from the morphogroup 4 (i.e. H. sosybius) possessing all the characters specified by Seraphim et al. (2014) and are very different from those of $H$. hermes [see Forster (1964) and Seraphim et al. (2014) for illustrations]. Most obviously, $H$. hermes has much longer saccus compared to shorter and more constricted in the middle valvae. Nevertheless, in addition to at least $2 \%$ different barcodes, south Texas morphogroup 4 populations differ from eastern H. sosybius in facies to the extent that researchers have been treating them as a species distinct from $H$. sosybius (Miller and Brown 1981, Pelham 2008, Warren et al. 2013). Our analysis agrees with this conclusion. Furthermore, we find subtle, but quantifiable, differences in male genitalia between $H$. sosybius and south Texas Hermeuptychia populations. Evidence presented above suggests that the name $H$. hermes should not be applied to them. Since currently there are no named species in the $H$. sosybius group [i.e., molecular group $\mathrm{G}$ and morphogroup 4 of Seraphim et al. (2014)] other than H. sosybius, and south Texas populations fall confidently in the $H$. sosybius group (Fig. 66a), they represent an unnamed species that is described here.

\section{Hermeuptychia hermybius Grishin, sp. $\mathrm{n}$.}

http://zoobank.org/B719B2F8-D0AD-4995-8372-6AA2FC2116E3

http://species-id.net/wiki/Hermeuptychia_hermybius

Figs 48-59, 60b, e, h, k, 61b, 62a-m, 63 part, 64q-z, 66 part, 67 part, 70

Description. Male ( $\mathrm{n}=56$, Figs 48-49, 52-56, 58-59) - holotype forewing length $=16$ $\mathrm{mm}$. Forewing triangular, rounded at apex and tornus, costal and outer margins convex, inner margin almost straight, mildly concave mediad, two discal cell veins budged at bases, vein $2 \mathrm{~A}$ thickened basad. Hindwing rounded, almost circular. Wings dorsally 
dark-brown with sparse olive-beige overscaling and two darker-brown terminal lines. Wings ventrally pale-brown, paler towards inner margin of forewing, with extensive beige overscaling, particularly along veins in distal part in some specimens; submedial and postmedial darker- to rusty- and olive-brown lines and end-of-cell streak (smaller on hindwing) between them; hindwing postmedial line more undulate that in $H$. sosybius, with a stronger bend in $\mathrm{M}_{1}-\mathrm{M}_{2}$ cell; two terminal dark-brown evenly curved marginal lines, dark-brown sinuous submarginal line, more undulate than in $H$. sosybius, barely touching the eyespot in cell $\mathrm{Cu}_{1}-\mathrm{Cu}_{2}$, and row of submarginal eyespots basad of the sinuous line and posteriad of postmedial line, eyespots frequently reduced in size and are more uniformly sized than in $H$. sosybius; usually largest eyespots black-centered and pupiled with pale-blue scales: on forewing, eyespots about the same size, frequently larger posteriad, but eyespot in cell $M_{1}-M_{2}$ (usually not the largest in size) and eyespot in cell $\mathrm{R}_{5}-\mathrm{M}_{1}$ (in some specimens) black-centered (more eyespots black centered in some specimens); on hindwing, largest eyespots in cells $M_{1}-M_{2}$ and $\mathrm{Cu}_{1}-\mathrm{Cu}_{2}$, a smaller one in cell $\mathrm{Cu}_{2}-1 \mathrm{~A}+2 \mathrm{~A}$, even smaller, but still black-centered and pale-blue pupilled in cell Rs- $\mathrm{M}_{1}$, and two smallest, usually without black, but in some specimens pale-blue pupilled eyespots in cells $\mathrm{M}_{2}-\mathrm{M}_{3}$ and $\mathrm{M}_{3}-\mathrm{Cu}_{1}$. Fringes monochrome, a little paler than the ground color of wings. Head, palpi, thorax and abdomen dark-brown above, paler and mostly beige beneath. Antennae dark-brown above with pale scales at segments, orange-brown at the club, beneath beige basad, orange-brown in distal half. Legs brown with beige scales. Male genitalia ( $n=19$, Figs 60b, e, h, k, 61b, 62a-m, 63 part) - typical for the genus, very similar to those of $H$. sosybius. Tegumen dome-like, rounded at margins. Uncus leaf-shaped in dorsal view, almost flat distally but convex basally in lateral view, with a well-developed thin, membranous carina in basal half; apex of uncus appears truncated in dorsal view and sides usually less concave than in $H$. sosybius. Gnathos arms thin, wide apart, divergent, about the same length as uncus. Valvae narrow, but typically broader than in H. sosybius, elongated with thin cuculli extending past gnathos usually farther than a quarter of their length; cucullus usually with four apical teeth; cucullus ventrally with inner medial bulge. Saccus about the same length as cucullus, narrow. Aedeagus elongated, bent around its middle, with a medium length phallobase. Female ( $n=45$, Figs 50-51, 57) - similar to male in facies, with slightly more rounded wings and dorsally paler in color. Female genitalia $(n=9$, Fig. 64q-z) as in H. sosybius, with pale, yellowish, weakly sclerotized and broad, rounder anteriad, cup-like antrum slightly asymmetric to the left. Ostium bursae ellipsoidal, its ventral margin shorter or equal to dorsal margin. Ductus and corpus bursae each in length similar to antrum; corpus bursae with two signa, spines in a signum narrow, leaf-shaped, placed in three to five irregular rows.

Barcode sequences. Full length DNA barcodes were obtained for 19 paratypes (GenBank accessions: KJ025569-KJ025587). The most common haplotype present in 17 sequences (including all 5 barcoded siblings of the holotype) is exemplified by the voucher NVG-1603, Genbank accession KJ025569, 658 base pairs:

AACTTTATATTTTATTTTTGGTATTTGAGCAGGAATAATTGGAACATCATTAAGTTTAATTATTCGAATAGAGTTAGGTAATCCAGGATTTT- 


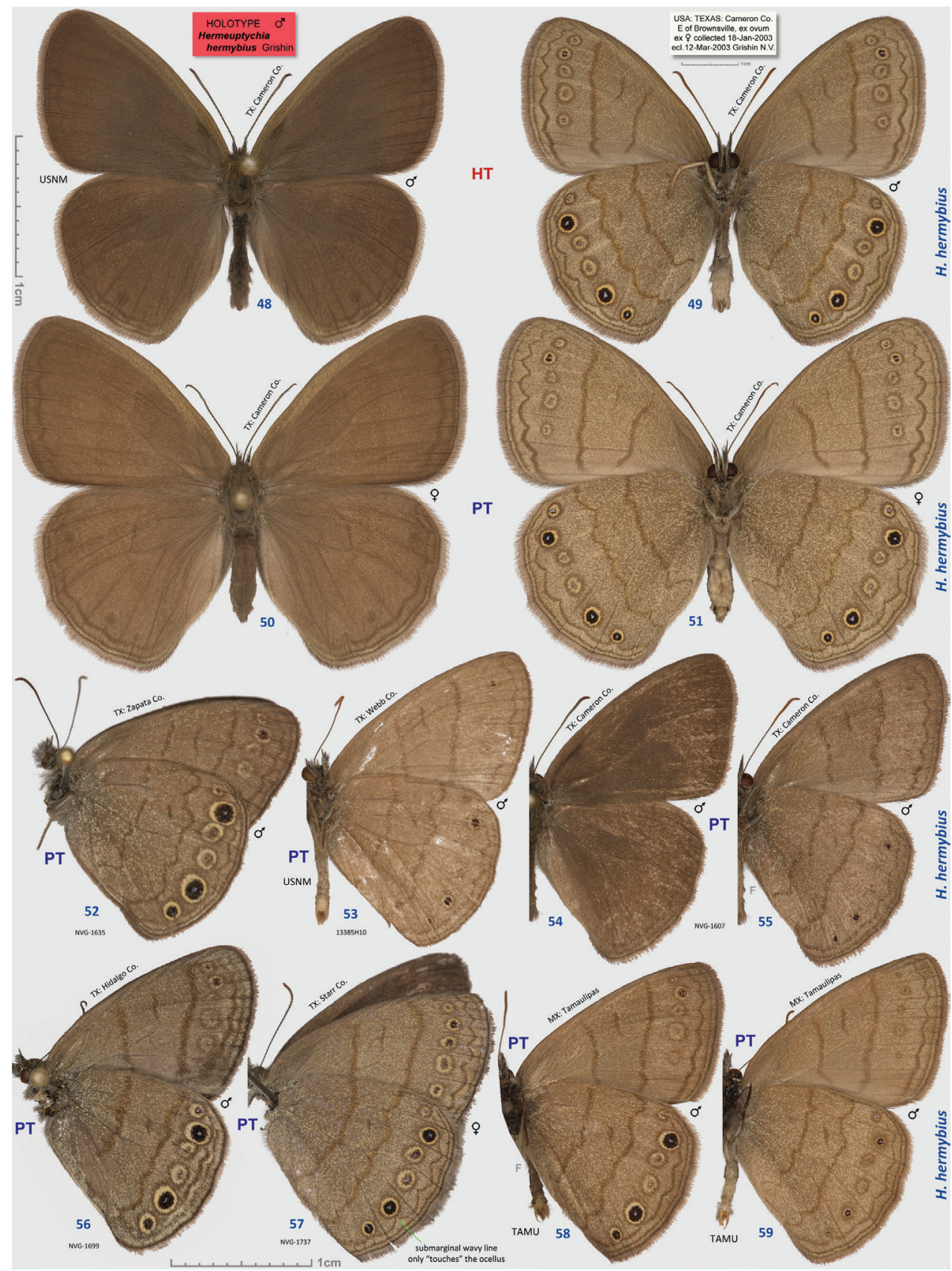

Figures 48-59. Hermeuptychia hermybius. 48-49 holotype, others are paratypes, data in text and Table 1. Sexes and DNA or genitalia voucher codes, or data: 50-5 I $q$ USA: Texas: Cameron Co., Brownsville,

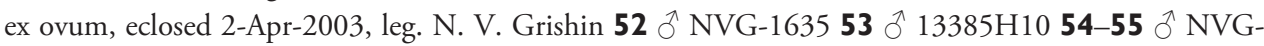

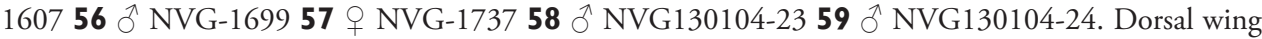
surfaces are in 48, 50, 54 others are ventral. Labels are shown for the holotype and are reduced 2.5-fold compared to specimens as indicated by a smaller scale bar. "F" specifies mirror image (left-right inverted). 
TAATTGGAGATGACCAAATTTATAACACTATTGTTACAGCCCATGCTTTTATTATAATTTTTTTTATAGTAATACCTATTATAATTGGAGGATTTGGTAATTGACTTATTCCTTTAATATTAGGAGCTCCTGATATAGCTTTCCCACGTATAAATAATATAAGATTTTGATTATTACCCCCATCTTTAATTTTATTAATTTCTAGTAGTATTGTAGAAAATGGAAGTGGAACAGGATGAACTGTTTACCCCCCTCTTTCATCTAATATTGCCCATAGAGGTTCTTCAGTAGATTTAGCAATTTTTTCTCTTCATTTAGCTGGAATTTCATCAATTTTAGGAGCCATTAATTTTATTACAACAATTATTAATATACGAATTAATAATATATCTTATGATCAAATACCTTTATTTATTTGAGCTGTAGGAATTACAGCTCTTCTTTTACTTCTCTCATTACCTGTTTTAGCAGGAGCTATTACCATACTTCTTACTGATCGAAATTTAAATACATCATTTTTTGACCCTGCAGGAGGAGGAGATCCTATTTTATATCAACATTTATTT

The 2 remaining sequences were identical to each other (Fig. 66b) and differed from the sequence shown above by a single base pair $(0.15 \%)$. Barcode from the oldest and westernmost specimen (TX: Laredo, 15-Apr-1949) was additionally verified with both DNA ID tags as described in Materials and methods section and confirmed to be this species.

Type material. Holotype: $\hat{\sigma}$, has the following two rectangular labels: white printed - || USA: TEXAS: Cameron Co. | E of Brownsville, ex ovum | ex $\rightarrow$ collected 18-Jan-2003 | ecl. 12-Mar-2003 Grishin N.V. ||; red printed - || HOLOTYPE ふे | Hermeuptychia| hermybius Grishin ||. The holotype is illustrated in Figs 48-49. Upon publication, the holotype will be deposited in the National Museum of Natural History, Smithsonian Institution, Washington, DC (USNM). Paratypes: $550 \widehat{\delta}$ and $45 q+$, from USA: Texas, unless indicated otherwise. Of these, $9 \hat{0} \delta$ and $12 q q$ are siblings of the holotype read from ova, with the same data, their sexes, eclosion dates and GenBank accessions|DNA voucher numbers|genitalia codes (where available, and in this format for other paratypes) are: 1 ㅇ 8-Mar-2003; 1 ภ 9-Mar-2003,

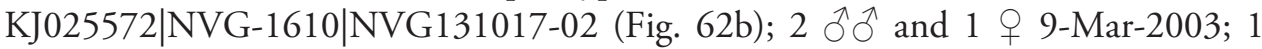

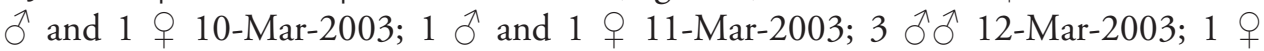
14-Mar-2003, KJ025573|NVG-1611|NVG131017-03 (Fig. 64s-t); 1 q 15-Mar2003; 1 q 16-Mar-2003, KJ025574|NVG-1612|NVG131017-04 (Fig. 64u-v); 1 q 17-Mar-2003, KJ025569|NVG-1603|NVG130927-17 (Fig. 64q-r); 2 우 17-Mar2003; 1 † 21-Mar-2003; 1 § 30-Mar-2003, KJ025571|NVG-1609|NVG131017-01 (Fig. 62a); 1 ๆ 2-Apr-2003 (Figs 50-51). Other paratypes are: $1 \hat{\jmath}$ ibid., collected on wing 18-Jan-2003, KJ025570|NVG-1607|NVG130927-18 (Figs 54-55, 60b, e, h, k). 1 q Cameron Co., E of Brownsville, 19-Oct-1997, leg. N. V. Grishin, KJ025575|NVG-1628|NVG131017-05. 1 đ Cameron Co., Brownsville, \{10-13\}Mar-1979, leg. T. Friedlander, NVG140104-01 [TAMU] (Fig. 62c). 1 đे (06-Jun2007) 1 q (07-Jun-2007) Cameron Co., Los Fresnos, Ted Hunt \& Loop Rd., leg. William R. Dempwolf. 4 q 9 Hidalgo Co., 1.5 air mi SE of Relampago, Rio Rico Rd., 26.07 -97.891, 21 m, 13-Jun-2013, leg. W. R. Dempwolf; 2 $\widehat{\jmath}$ ibid., 19Oct-2013, KJ025577|NVG-1698|NVG131229-04 (Fig. 62d) and KJ025578|NVG1699|NVG131229-05 (Figs 56, 62e); 1 q ibid., 19-Oct-2013, KJ025576|NVG1695|NVG131229-03 (Fig. 64w-x); 3 ふึ 4 우 ibid., 19-Oct-2013; 2 ふふર 4 우 


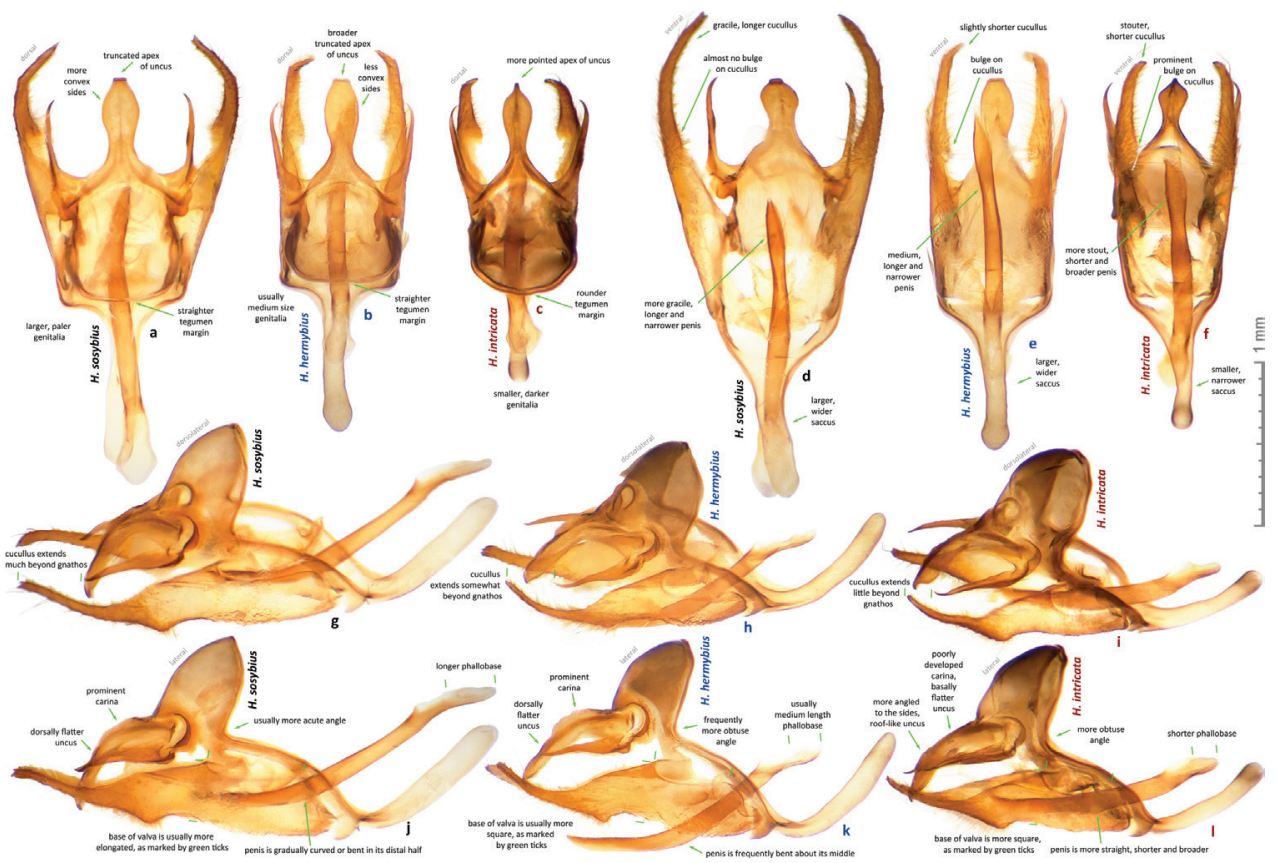

Figure 60. Male genitalia of Hermeuptychia from USA: Texas. a, d, g, j H. sosybius, Fort Bend Co., Brazos Bend State Park, Horseshoe Lake trail, 29²2'54.96" -95³6'41.06", 15 m, 17-Aug-2013, leg. N. V. Grishin, DNA voucher NVG-1542, genitalia NVG130927-03 (forewing length $15 \mathrm{~mm}$ ) b, e, h, k H. hermybius sp. n. paratype, Cameron Co., E of Brownsville, 18-Jan-2003, leg. N. V. Grishin, DNA voucher NVG-1607, genitalia NVG130927-18 (specimen Figs 54-55, forewing length 15.5 mm) c, f, i, I H. intricata sp. n. holotype, Fort Bend Co., Brazos Bend State Park, near Hale Lake, $29^{\circ} 22^{\prime} 48.27^{\prime \prime}-95^{\circ} 35^{\prime} 05.02 ", 16$ m, 17-Aug-2013, leg. N. V. Grishin, DNA voucher NVG-1560, genitalia NVG130927-14 [USNM] (specimen Figs 22-23, forewing length 16.5 mm). Views: a-b dorsal, perpendicular to the tegumen-uncus-gnathos plane $\mathbf{c}-\mathbf{d}$ ventral, perpendicular to the plane of saccus and valvae (appears larger than dorsal view due to different projection axis) $\mathbf{e}-\mathbf{f}$ right dorsolateral $\mathbf{g}-\mathbf{h}$ right lateral. All images are to scale. Diagnostic characters are indicated on images. Note that $H$. intricata with larger than $H$. sosybius wings has smaller genitalia.

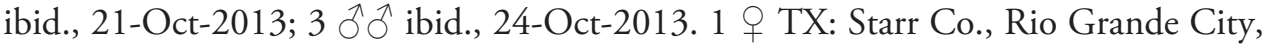
Fort Ringgold, 26.3707 -98.8064, 45 m, 12-Nov-2010, leg. W. R. Dempwolf; 1 ㅇ ibid., 13-Jun-2013; 1 ô ibid., 20-Oct-2013, KJ025580|NVG-1714|NVG131229-07

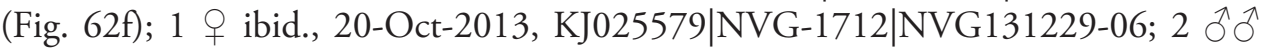

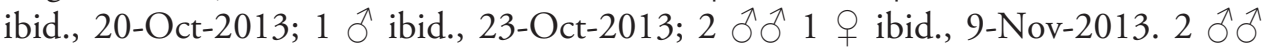
Starr Co., Roma, S of Roma International Bridge, 26.4035 -99.0175, 50 m, 20-Oct2013, leg. W. R. Dempwolf, KJ025581|NVG-1726|NVG131229-08 (Fig. 62g) and

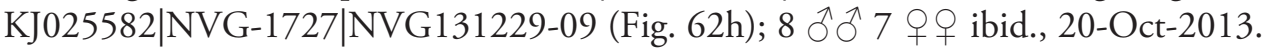
1 ㅇ Starr Co., Roma Creek, Hwy 650/Hwy 83, 29-Oct-2007, leg. W. R. Dempwolf. 2 우우 Starr Co., 0.5 mi S of Fronton, 26.399 -99.085, 50 m, 20-Oct-2013, leg. W. R. Dempwolf, KJ025583|NVG-1735|NVG131229-10 and KJ025584|NVG- 


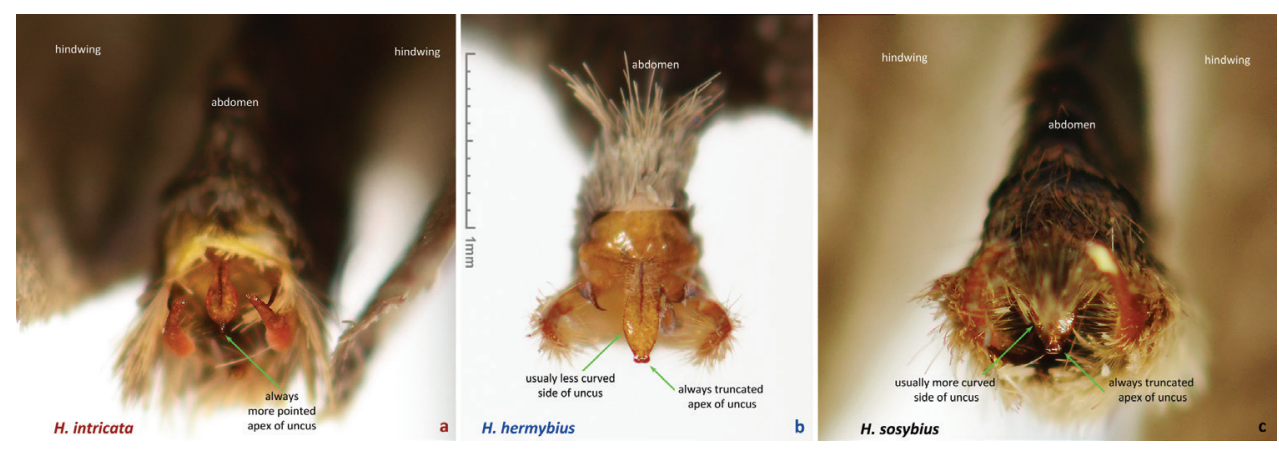

Figure 6I. Dorsoposterior view of male abdomens of Hermeuptychia from USA: Texas. a H. intricata, DNA voucher NVG-1548 (mirror image, i.e. left-right inverted) b $H$. hermybius, DNA voucher NVG1635 (also shown in Fig. 62j, specimen Fig. 52) c H. sosybius, DNA voucher NVG-1553. Data in Table 1. Scales are brushed off the abdomen tip to expose distal parts of genitalia. The easiest to observe character (the shape of the distal end of uncus) is indicated.

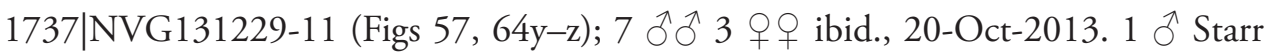
Co., Salineno @ Rio Grande, 26.51463 -99.11633, 53 m, 23-Oct-2013, leg. W. R. Dempwolf, KJ025585|NVG-1747|NVG131229-12 (Fig. 62i). 1 ð Zapata Co., San Ygnacio @ Rio Grande, 92 m, 7-Oct-2007, leg. N. V. Grishin, KJ025586|NVG1635|NVG131017-12 (Figs 52, 61b, 62j). 1 ô Webb Co., Laredo, 15-Apr-1949, leg. E. L. Todd KJ025587|13385H10|NVG131102-53 [USNM] (Figs 53, 62k). 1 ठ Mexico: Tamaulipas: Rt. 101 at Rio Corona, 1-Jan-1980, leg. P. W. Kovarik \& D. S. Bogar, NVG140104-04 [TAMU]. 1 ते Mexico: Tamaulipas: El Canindo, nr. Ejido San José, 7.5 km W Gómez Farías, 1400 m, \{19-21\}-Jul-1994, leg. C. Cate \& T. Ri-

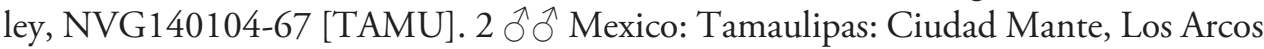
Ct., 19-Dec-1973, leg. R. O. \& C. A. Kendall, NVG140104-22 and NVG130104-23 [TAMU] (Figs 58, 62 m); 1 O ibid., 28-Jan-1995, ex larva, foodplant Panicum maximus Jacq., NVG140104-24 [TAMU]. 1 ก Mexico: Tamaulipas: Quintero cave [22.6333 -99.0333], 7-Jan-1974, leg. R. O. \& C. A. Kendall, NVG130104-24 [TAMU] (Figs 59, 621). 1 त 1 q Mexico: San Luis Potosí: El Salto Falls, 30-Dec-1979, leg. P. W. Kovarik \& D. S. Bogar, NVG140104-03 and NVG140104-02 [TAMU].

Type locality. USA: Texas: Cameron County, east of Brownsville. It is a shaded area covered in Guinea grass (Panicum maximus), situated near a ravine and overgrown with taller trees.

Etymology. The name is a fusion of two words: herm[es] beginning and [sos] ybius ending. It symbolizes that this species traditionally and previously regarded as $H$. hermes is phylogenetically closer to H. sosybius, and yet is distinct from it. The resulting word is unique and currently unknown to internet search engines, which is expected to ease its searches. The name is a noun in apposition.

Distribution. This species is currently recorded from the lower Rio Grande Valley region of Texas along the Rio Grande from Laredo to the Gulf coast (Webb, Za- 


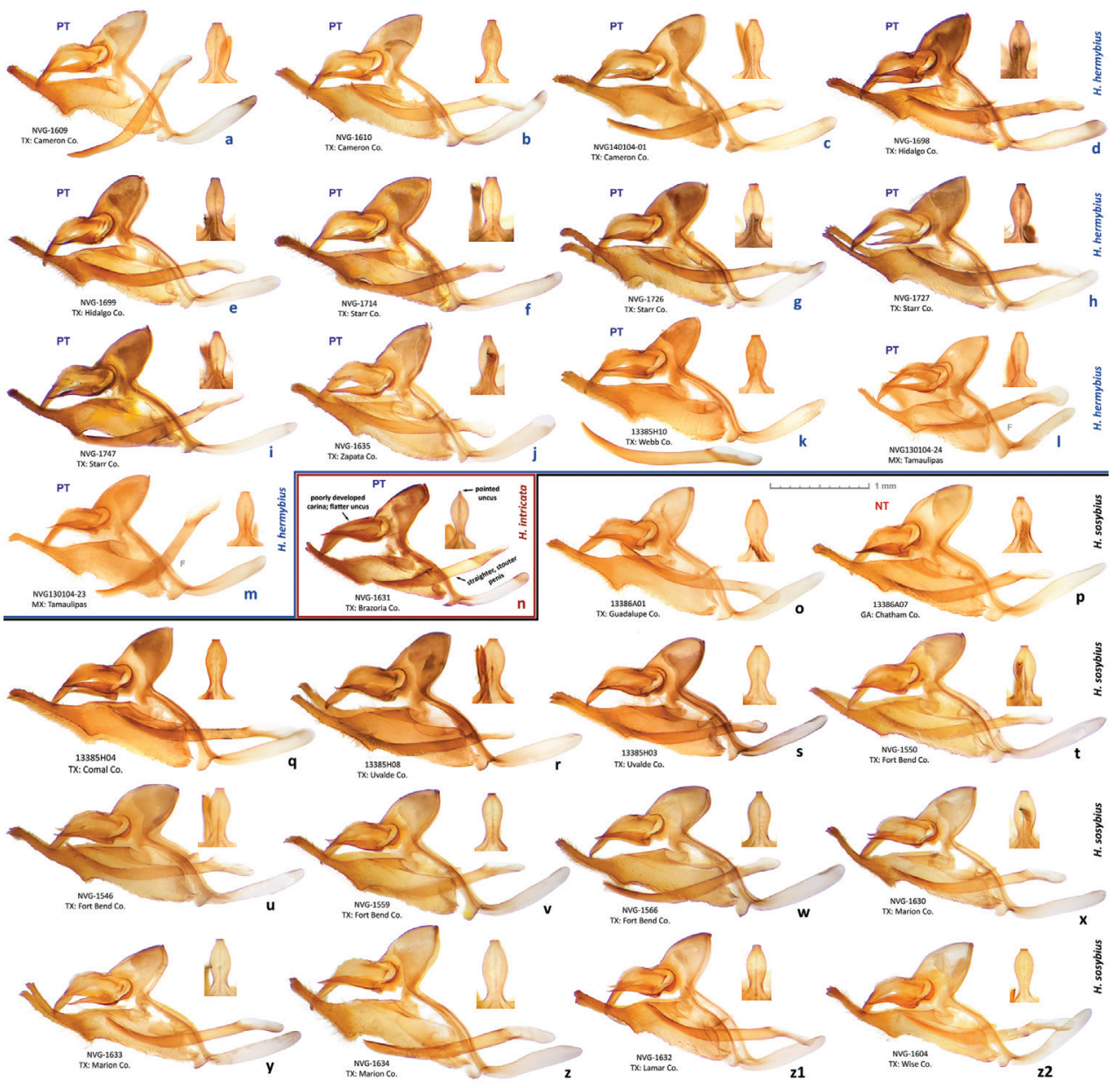

Figure 62. Variation in male genitalia of $H$. hermybius and $H$. sosybius. a-m $H$. hermybius paratypes, DNA (or genitalia, where DNA sequence is not available, and full data for these given) voucher codes: a. NVG-1609 b NVG-1610 c Texas: Cameron Co., Brownsville \{10-13\}-Mar-1979, T. Friedlander, NVG140104-01 d NVG-1698 e NVG-1699 (specimen Fig. 56) f NVG-1714 g NVG-1726 h NVG1727 i NVG-1747 j NVG-1635 (also shown in Fig. 61b, specimen Fig. 52) k 13385 H10 (specimen Fig. 53) I-m Mexico: Tamaulipas, leg. R. O. \& C. A. Kendall: I Quintero cave, 7-Jan-1974, NVG130104-24 (specimen Fig. 59) m Ciudad Mante, Los Arcos Ct., 19-Dec-1973, NVG130104-23 (specimen Fig. 58) n H. intricata paratype, NVG-1631 (specimen Figs 28-29), diagnostic characters are indicated on the image o-z2 H. sosybius: o 13386A01 (specimen Fig. 47) p 13386A07, neotype (specimen Figs 9-11) q $13385 \mathrm{H} 04$ r $13385 \mathrm{H} 08$ (specimen Fig. 46) s 13385H03 t NVG-1550 u NVG-1546 v NVG-1559 w NVG-1566 x NVG-1630 y NVG-1633 z Texas: Marion Co., W of Caddo Lake, 5-Apr-1997, leg. N. V. Grishin, NVG-1634 zI NVG-1632 z2 Texas: Wise Co., LBJ National Grassland, ex ovum, eclosed 3-Aug-1998, leg. N. V. Grishin, NVG-1604. c, I, $\mathbf{m}$ are in TAMU and $\mathbf{o - s}$ are in USNM collections. Data for most specimens are in Table 1, text, or specified above. Complete genitalia are shown in lateral view, and dorsal view of uncus is shown above and to the right of each specimen. Aedeagus is shown below in $\mathbf{k}$ DNA (or genitalia, where DNA sequence is not available) voucher codes and general localities are indicated below each genitalia image. "F" specifies mirror image (left-right inverted). 


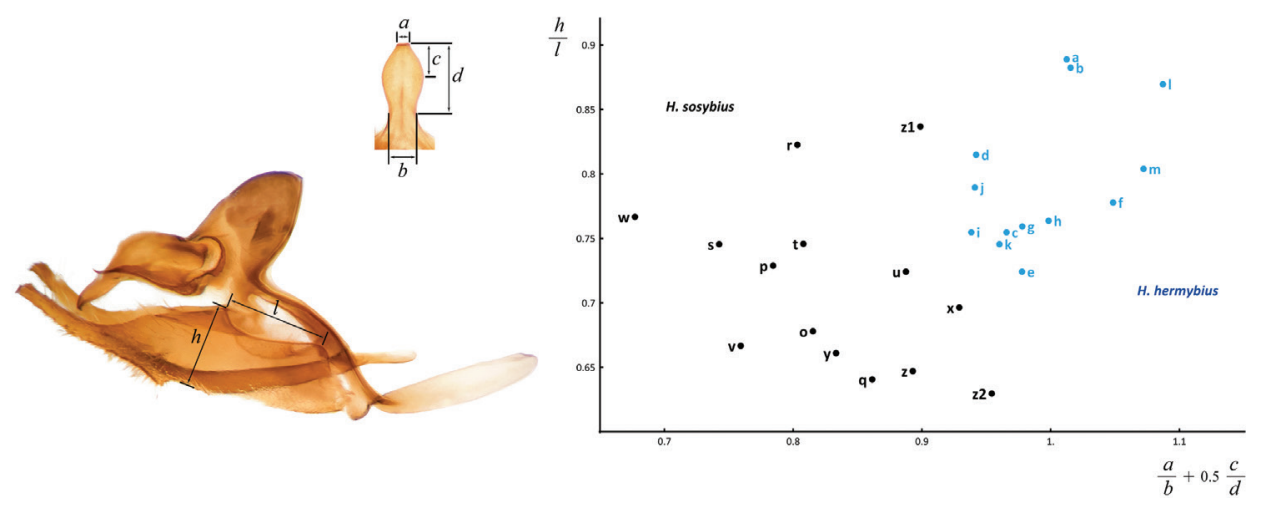

Figure 63. Morphometric differences between male genitalia of $H$. sosybius (black) and H. hermybius (blue). Measurements used are marked on dorsal view of uncus (top left) and on lateral view of complete genitalia (bottom left): $\mathbf{a}$ width of uncus at the apex $\mathbf{b}$ width of uncus at the narrowest point near the base ("neck" at the joint with tegumen) $\mathbf{c}$ distance from the uncus apex to the cross-section at the widest point d distance from the uncus apex to the cross-section at the narrowest point near the base $\mathbf{1}$ length of valval dorsal "window" $\mathbf{h}$ height of valva (in lateral view) at the end of the dorsal "window", direction of height measurement is perpendicular to the direction of length measurement. Measurements of genitalia shown in Fig. 62 are plotted on the right. Horizontal axis combines all uncus measurements into a formula $a / b+0.5^{*} c / d$ and vertical axis shows measurements of valva as $h / l$. Each point corresponds to a specimen and a letter next to it is the same one that denote its genitalia in Fig. 62.

pata, Starr, Hidalgo, and Cameron Counties, Fig. 67) and in neighboring Mexico (Tamaulipas, San Luis Potosí).

Diagnosis. In wing pattern, the new species is most similar to $H$. sosybius, but typically can be differentiated from it by: (a) eyespots that are not only smaller, but also more uniform in size, i.e. out of 5 forewing eyespots, 4 (except the one near costa) are usually about the same size, and the eyespot that is black-ringed in most specimens (second from costa) is typically not the largest (this eyespot is frequently the largest in H. sosybius), but the next-to-last eyespot ( $4^{\text {th }}$ from the costa) is usually the largest one; (b) more undulate postmedial line on ventral hindwing, that frequently strongly bulges basad by the largest eyespot near apex (in cell $\mathrm{M}_{1}-\mathrm{M}_{2}$ ); (c) more undulate submarginal sinuous line, which on ventral hindwing barely touches the largest eyespot near the tornus (in cell $\mathrm{Cu}_{1}-\mathrm{Cu}_{2}$, second eyespot from tornus, indicated in Fig. 57)-this line is usually fully merged with this eyespot border for some distance in $\mathrm{H}$. sosybius. Wingbased identification is not absolute due to extensive pattern variation in both species.

In male genitalia, the new species is also closest to H. sosybius and should be attributed to the same morphogroup 4 of Seraphim et al. (2014). It differs from H. sosybius in the following trends (Figs 60-61): (1) uncus is less convex and narrower on the sides in dorsal (or ventral) view, with a broader truncated apex, the width at the apex is usually more than $2 / 3$ of the width at the narrowest point near the base (Figs 60b, e, 61b); (2) valva is typically "higher" in lateral view (dorso-ventral direction), more square at the base (Fig. 60k) and is less extended (Fig. 60h); (3) aedeagus is somewhat broader 


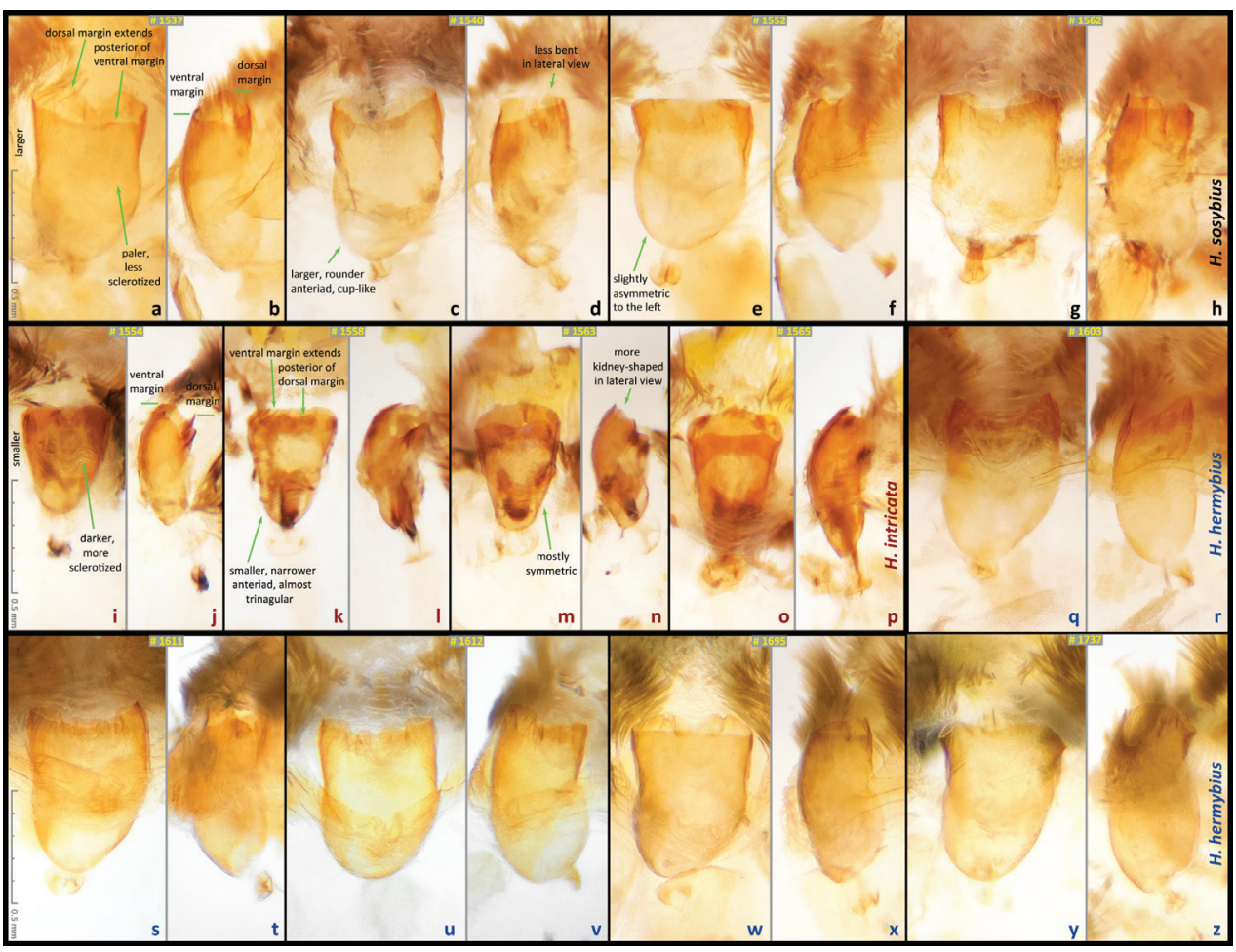

Figure 64. Antrum in female genitalia of Hermeuptychia from USA: Texas. a-h H. sosybius, Fort Bend Co., Brazos Bend State Park, 17-Aug-2013, leg. N. V. Grishin: a-f is from Horseshoe Lake trail, 29 $22^{\prime} 54.96^{\prime \prime}-95^{\circ} 36^{\prime} 41.06^{\prime \prime}, 15 \mathrm{~m}$ and $\mathbf{g}-\mathbf{h}$. is from near Hale Lake, 29 $22^{\prime} 48.27^{\prime \prime}$ -95 35'05.02", 16 m; DNA voucher|genitalia dissection codes are: a-b NVG-1537|NVG130927-01 c-d NVG-1540|NVG130927-02 (specimen Fig. 12) e-f NVG-1552|NVG130927-06 g-h NVG1562|NVG130927-10 i-p H. intricata sp. n. paratypes, Fort Bend Co., Brazos Bend State Park, near Hale Lake, 29²2'48.27" -95³5'05.02", 16 m, 17-Aug-2013, leg. N. V. Grishin; DNA voucher|genitalia dissection codes: i-j NVG-1554|NVG130927-07 (specimen Fig. 24) k-I NVG1558|NVG130927-08 m-n NVG-1563|NVG130927-11 o-p NVG-1565|NVG130927-12 (specimen Fig. 25) q-z H. hermybius sp. n. paratypes q-r Cameron Co., E of Brownsville, ex ovum ex $ᄋ$ captured on 18-Jan-2003, eclosed on 17-Mar-2003, leg. N. V. Grishin, NVG-1603|NVG130927-17 s-t ibid., eclosed on 14-Mar-2003, NVG-1611|NVG131017-03 u-v ibid., eclosed on 16-Mar-2003, NVG-1612|NVG131017-04 w-x TX: Hidalgo Co., 1.5 air mi SE of Relampago, Rio Rico Rd., 26.07 -97.891, 21 m, 19-Oct-2013, leg. W. R. Dempwolf, NVG-1695|NVG131229-03 y-z Starr Co., 0.5 mi S of Fronton, 26.399 -99.085, 50 m 10-Oct-2013, leg. W. R. Dempwolf, NVG-1737|NVG131229-11 (specimen Fig. 57). Additional data for specimens and their DNA barcodes are in Table 1. In all images, posterior end is pointing up (i.e. ostium bursae is closer to the top of each image); a, c, e, g, i, k, $\mathbf{m}, \mathbf{o}, \mathbf{q}, \mathbf{s}, \mathbf{u}, \mathbf{w}, \mathbf{y}$ are in lateral view, others are in right ventrolateral view. All images are to scale. Diagnostic characters to tell between $H$. sosybius and $H$. intricata are indicated on images, each character was invariantly observed in all inspected samples of a species, but is indicated (for clarity) on a single image only. We failed to find characters distinguishing female genitalia of $H$. hermybius from $H$. sosybius and simply illustrate genitalic variation. 


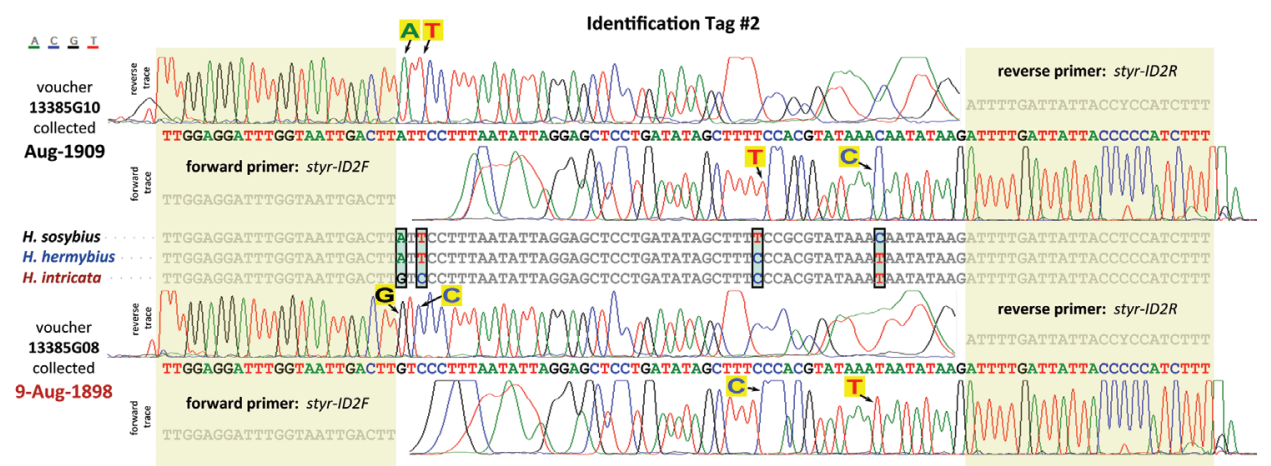

Figure 65. DNA ID tags of specimens that are over 100 years old. ID tag \#2 is shown as an example. The tag region sequence alignment of the three species: H. sosybius, H. hermybius, and H. intricata is shown in the middle and positions at which sequences differ are highlighted in cyan and boxed. Each of the three species differs from the other two by at least 2 nucleotides, and $H$. sosybius is different from $H$. intricata by 4 nucleotides. Forward and reverse primer regions are shaded. DNA of the tag was amplified and sequenced in both forward and reverse directions from two over-100-years-old specimens from the same locality (SC: Clarendon Co.). Forward and reverse sequences traces for the first specimen are shown above the reference sequences and the two traces for the second specimen are shown below. It is clear from the traces that the specimen above $(13385 \mathrm{G} 10$, Fig. 36$)$ is $H$. sosybius, (A, T, T, \& C at these 4 positions, no contamination seen) and the one below (13385G08, Fig. 33) is H. intricata (G, C, C, $\& \mathrm{~T}$ at these 4 positions and equally unambiguous traces). Nucleotides that identify each specimen are indicated in large letters on yellow background and arrows point to the trace peaks revealing these nucleotides. This strategy was applied to identify 12 very old specimens of three species in a random order and yielded unambiguous identifications for 11 of them. One sample appeared to be contaminated, and the traces showed the presence of several nucleotides in many positions. All 11 DNA-based identifications agreed with genitalic identifications.

and is frequently bent near its middle, with a medium length phallobase (Fig. 60e); (4) usually more obtuse angle formed by the tegumen and vinculum in lateral view (Fig. 60k). These characters are quite subtle, and as illustrated in Fig. 62 (compare panels $\mathrm{a}-\mathrm{m}$ with panels $\mathrm{o}-\mathrm{z} 2$ ) are subject to significant variation. In contrast, distinction of H. intricata (Fig. 62n for comparison) is always definitive and clear-cut. To evaluate the confidence of $H$. hermybius identification by male genitalia and to test the ability to differentiate this new species from $H$. sosybius by objective criteria, we resorted to morphometric analysis (Fig. 63). For simplicity, we have chosen to exploit only two trends listed above: (1) shape of uncus in dorsal view and (2) shape of valva base in lateral view. The shape of uncus was measured by the ratio of width at the apex $(a)$ to the width at the narrowest point near the base $(b)$, and by the ratio of the distance from apex to the widest point in cross-section $(c)$ to the distance from apex to the narrowest point near the base (d). We noticed that both of these ratios tend to be smaller in $H$. sosybius. Instead of applying PCA or other similar data-driven technique, which may be biased by the data at hand (i.e. the resulting transformation would change with the dataset used), we combined these measurements in a data-independent transforma- 

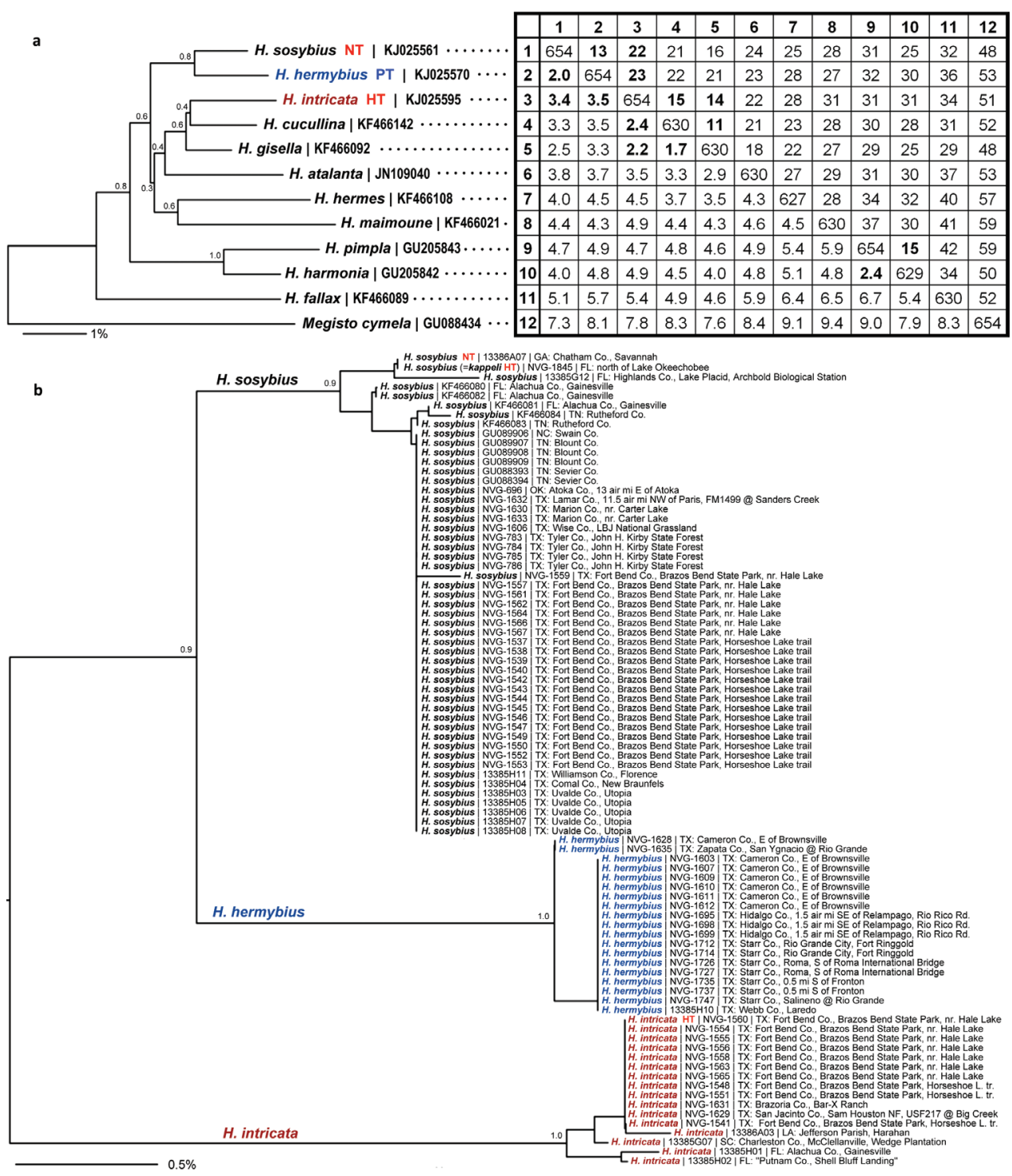

Figure 66. DNA-derived data. a Analysis of named Hermeuptychia species b relationships between Hermeuptychia specimens from USA in a form of BioNJ (Dereeper et al. 2008) distance tree. a DNA barcode distance matrix is shown on the right and a BioNJ distance tree corresponding to it is on the left. The tree is rooted with Megisto cymela (Cramer, 1777) sequence. A more comprehensive tree that includes several specimens of each species (except those described herein) and their detailed analyses are given in Seraphim et al. (2014) and is not repeated here. Only a single representative sequence for each species is used in a for clarity. The scale bar corresponding to about $1 \%$ difference in sequences is placed below the tree. Bootstrap support values are shown by each node in the tree; values below 0.5 indicate possibly incorrect groupings. GenBank accessions (http://genbank.gov/) for sequences are given after species names. NT, PT and HT refer to neotype, paratype and holotype, respectively. Data for specimens are in Table 1. Specimens 4-11 were not examined and their identification follows that of the authors 
tion. We used a weighted sum of the two ratios, with the weight of the second ratio arbitrarily set to half the weight of the first one: $a / b+0.5 c l d$, since the ratio of widths (first ratio) seemed to tell the species apart better than the ratio of lengths (second ratio). The shape of the valva base in lateral view was quantified by the ratio of length of the dorsal "window" (less sclerotized, membranous and flat segment along dorsal side near the base) to the height of the valva at the distal end of the "window". These variables were measured and computed on a diverse sample of 27 genitalia illustrated in Fig. 62. The resulting plot (Fig. 63 on the right) separated the two species. Therefore these simple measurements could be used to tell between these two cryptic Hermeuptychia species by male genitalia. However, we were not able to find characters in female genitalia to differentiate the new species from $H$. sosybius.

Finally, the most confident identification is provided by DNA barcode sequences (Fig. 66) that show little variation within each species (most sequences are identical across the range, maximum difference below $1 \%$ in $H$. sosybius), but reveal a definitive $2 \%$ hiatus between central and south Texas populations (Figs 66-67). We selected all positions that were invariant in the barcode sample of each species but different between the two species as characters to differentiate $H$. hermybius from $H$. sosybius. The resulting 11 positions are listed in the format " $\mathrm{k} X$ (not $\mathrm{Y}$ )", where $\mathrm{k}$ is a sequential number of the position (numbering is from 1 to 658 for the barcode sequence shown above as a reference), $\mathrm{X}$ is a nucleotide in $H$. hermybius barcodes and $\mathrm{Y}$ is a nucleotide in $H$. sosybius barcodes: $64 \mathrm{~T}$ (not C), $73 \mathrm{G}(\operatorname{not} \mathrm{A}), 82 \mathrm{~T}(\operatorname{not} \mathrm{C}), 118 \mathrm{C}(\operatorname{not} \mathrm{T}), 133 \mathrm{C}(\operatorname{not} \mathrm{T}), 235$ C (not T), 238 A (not G), 364 C (not T), 436 C (not T), 526 A (not T), 616 C $(\operatorname{not}$ T). These positions distinguish the two species; however, some of the positions are expected to show variation when a larger sample of sequence is accumulated.

Life history. The holotype of the new species, along with 21 paratypes are specimen reared in the lab from ova obtained from a captive female. All life history stages are illustrated in Fig. 70, and could be compared to the images of $H$. sosybius life history (Fig. 69). Immature stages of both species are very similar and without larger sample it is difficult to derive solid conclusions about the differences. Nevertheless, the following observations were made. Natural foodplants seems to be Panicum maximus (Guinea grass) per R. O. Kendall \& C. A. Kendall, who reared caterpillars found on

who performed sequencing studies and analyses (Рeña et al. 2010, Silva-Brandáo et al. 2011, Seraphim et al. 2014). Percent difference and the number of different nucleotides are shown below and above the diagonal in the matrix, respectively, and the length of each sequence segment (bp) used in the analysis is on the diagonal. Most instructive values discussed in the text are shown in bold font $\mathbf{b}$ GenBank accession numbers (those that start with letters $\mathrm{G}$ or $\mathrm{K}$ ) for sequences retrieved from GenBank or DNA voucher numbers (those that start from a number or letter $\mathrm{N}$ ) for sequences obtained in this study and locality data for specimens are given for each sequence. Further details about the specimens are provided in Table 1. H. sosybius specimens with sequences obtained from GenBank were not examined and their identification follows that of the authors who performed sequencing studies (Murray and Prowell 2004, Hebert et al. $2010 \&$ Seraphim et al. 2014). All H. hermybius and H. intricata specimens are paratypes, except the holotype marked with "HT". Scale bar shown below indicates about $0.5 \%$ difference. 


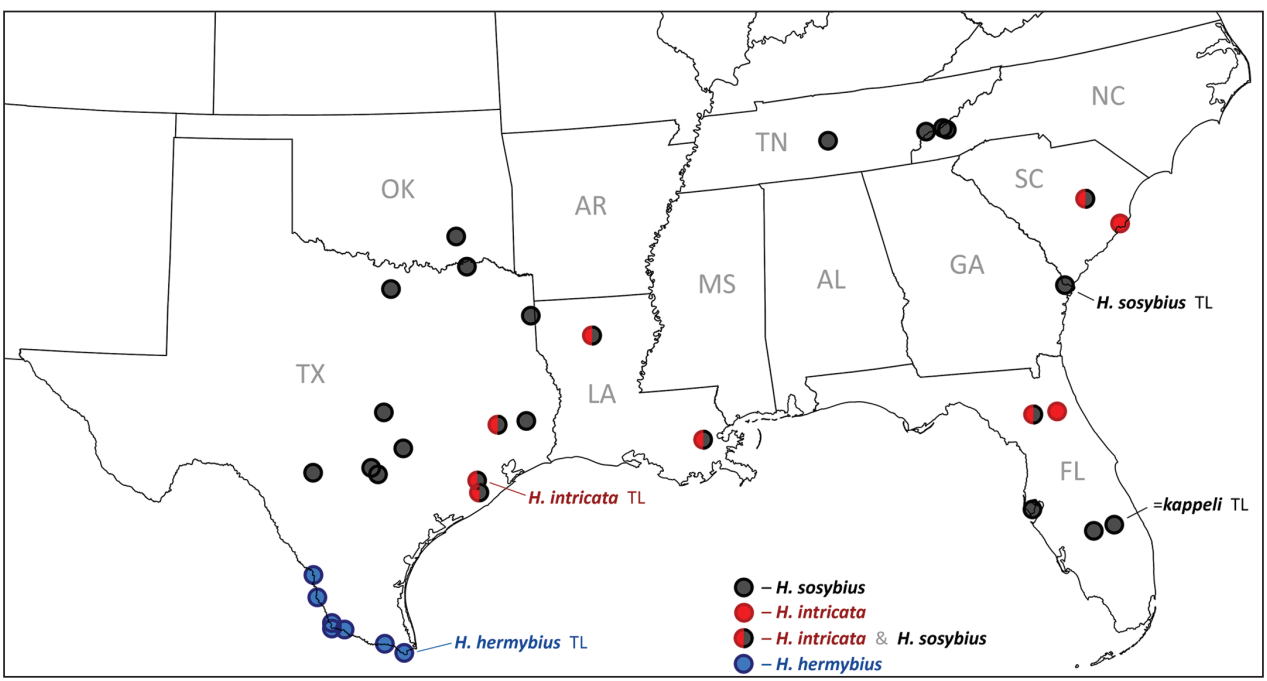

Figure 67. USA localities of Hermeuptychia specimens with available DNA barcode information. Color of circles corresponds to species: $H$. sosybius-black; $H$. hermybius-blue, $H$. intricata-red, split red/black circles mark localities where both $H$. sosybius and $H$. intricata were recorded. Type localities are indicated with a corresponding name followed by "TL". Hermeuptychia hermes kappeli was treated as a junior subjective synonym of $H$. sosybius by Pelham (2008). DNA barcode of $H$. h. kappeli holotype is $100 \%$ identical with the barcode of $H$. sosybius neotype. DNA barcode amplification failed for $H$. intricata specimen from LA: Jonesboro and for $H$. sosybius specimen from TX: Brazoria Co., and their identification is based on genitalia only. Specimens from all localities except those from TN and NC (data from GenBank, specimens not inspected) and from FL: St. Petersburg (specimen lacked abdomen) were dissected, and genitalia-based identification agreed with DNA barcode-based identification in all cases (see Fig. 66).

this grass in Mexico: Tamaulipas [TAMU collection]. This plant is also common in the lower Rio Grande Valley and is ubiquitously present where Hermeuptychia adults were encountered. Caterpillars hatched from eggs in captivity readily accepted Cynodon dactylon (L.) Pers. (Bermuda grass) and were successfully reared on it. Both H. sosybius and $H$. hermybius caterpillars go through four instars prior to pupation, and the first instar has black head capsule (Figs 69b-d, 70b-c). In subsequent instars, head capsule is green and round, without horns and projections (Figs $69 \mathrm{e}-\mathrm{m}, 70 \mathrm{~d}-\mathrm{m}$ ). Caterpillars of both species typically rest below leaves on loosely made silk pads, frequently in pairs, when two caterpillars face each other "head-to-head" (Figs 69h, 70c). When disturbed, caterpillars first curl into a $\mathrm{C}$ head-to-tail while legs being attached to the leaf (Figs 69f, j, 70e), then to a full $\mathrm{O}$, head-to-legs (Fig. 70g). White dorsolateral spots in ultimate instar seem to be more pronounced in $H$. hermybius than in $H$. sosybius (compare Fig. $70 \mathrm{~g}-\mathrm{k}$ with $69 \mathrm{k}$ ). Pupae of $H$. hermybius were stronger patterned with brown on the sides (Fig. 70o) than those of H. sosybius from two distant-from-each-other Texas localities (Fig. 69n-o), and some H. hermybius pupae were brown in color (Fig. 70n). 


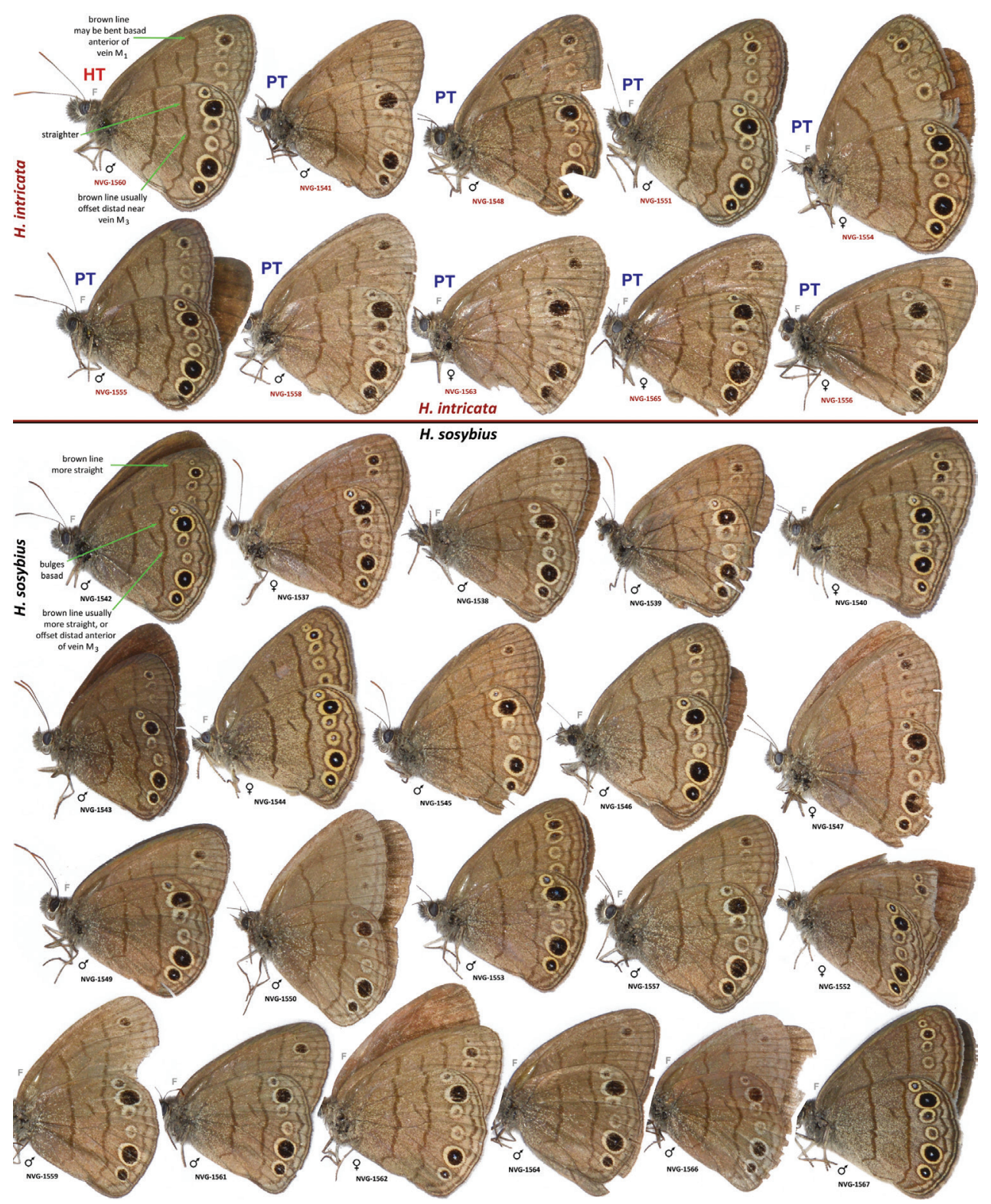

Figure 68. DNA-barcoded Hermeuptychia specimens from USA: Texas: Fort Bend Co., Brazos Bend State Park. H. intricata is above the line and H. sosybius is below the line, photographed prior to removal of body parts for DNA extraction. DNA voucher codes (see Table 1 for data) are shown below each specimen. Hypothetical field marks are indicated on the first specimen of each species. NVG-1537-NVG-1553 are from Horseshoe Lake trail, 29²2'54.96" -95'36'41.06", $15 \mathrm{~m}$; and

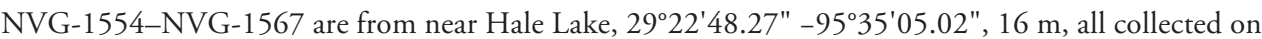
17-Aug-2013. Both species are present in each locality. Images are scaled approximately. "F" specifies mirror image (left-right inverted). 


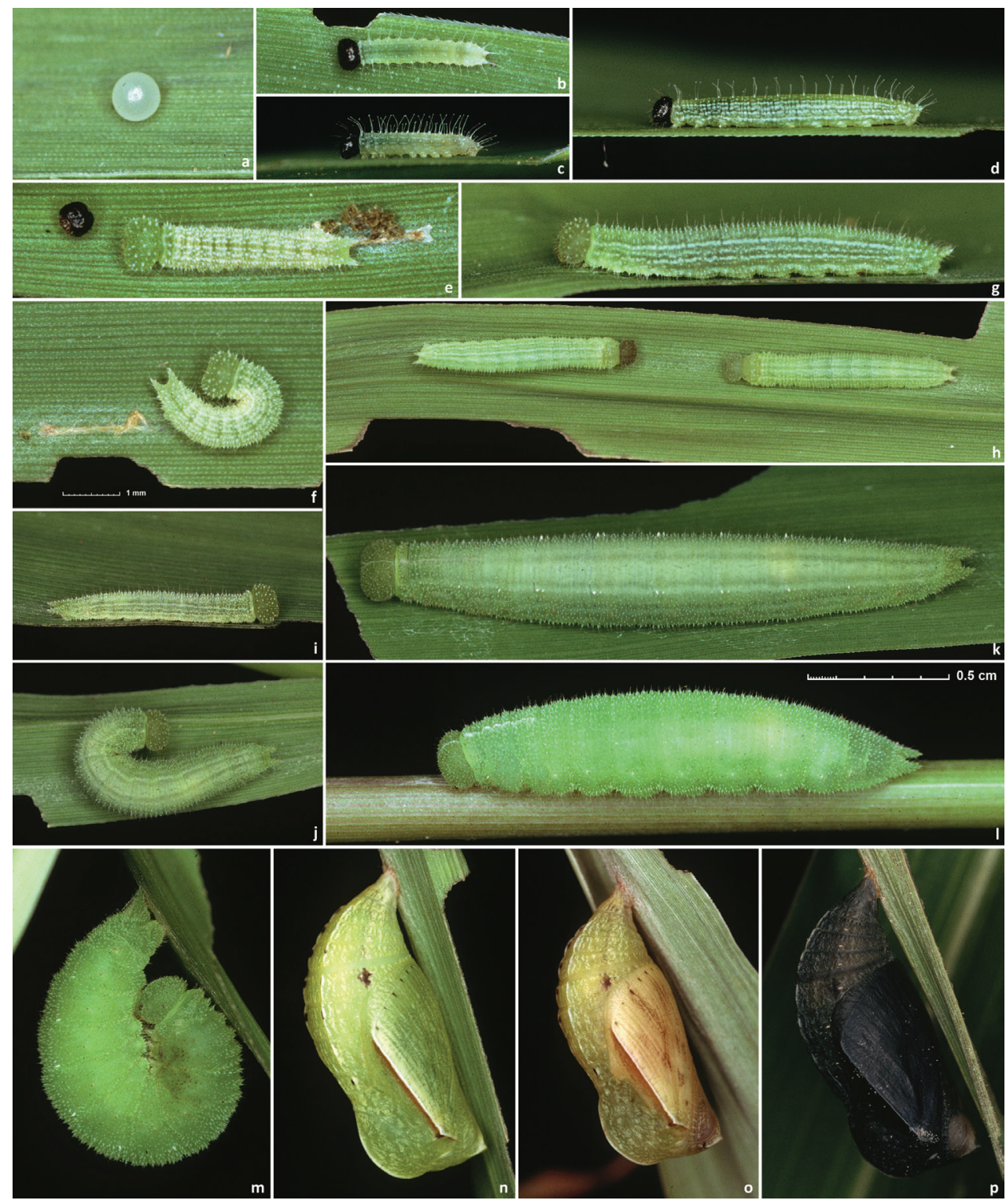

Figure 69. Life history of H. sosybius. USA: TX: Brazoria County, Bar-X Ranch, Rd. $971 \mathrm{~N}, 29.13252$ -95.58340, ex ovum ex $q$ collected on 4-Mar-2000, except o, which is TX: Wise Co., LBJ National Grassland. a ovum, 6-Mar-2000 b-d $1^{\text {st }}$ instars, photographed on 14- 14- \& 16-Mar-2000, respectively $\mathbf{e}-\mathbf{g} 2^{\text {nd }}$ instars photographed on 21-19- \& 21-Mar-2000 e, f are just after molt, shed larval skins are behind and $1^{\text {st }}$ instar head capsule (black) is on the left in $\mathbf{e}, \mathbf{f}$ is in a curled position adopted when disturbed $\mathbf{h}$ pre-molt quiescent $2^{\text {nd }}$ instar larvae in a typical "head-to-head" resting position, 24-Mar-2000 $\mathbf{i}-\mathbf{j} 3^{\text {rd }}$ instars, 24- \& 27-Mar$2000 \mathbf{k}-\mathbf{I} 4^{\text {th }}$ (ultimate) instars, $\widehat{\partial} \hat{\sigma}, 3-\&$ 6-Apr-2000 I close to pupation, note the color and shape change m prepupa, 6-Apr-2000 n-p pupae, 9-Apr-2000, 8-Aug-1998, \& 17-Apr-2000 o is from Wise Co., wing color is starting to develop $\mathbf{p}$ near eclosion, dark adult is seen through semi-transparent pupal cuticle. Most images show different individuals. Images $\mathbf{a}-\mathbf{g}$ are enlarged 2 times (scale on $\mathbf{f}$ ) compared to the rest (scale on $\mathbf{l}$ ). 


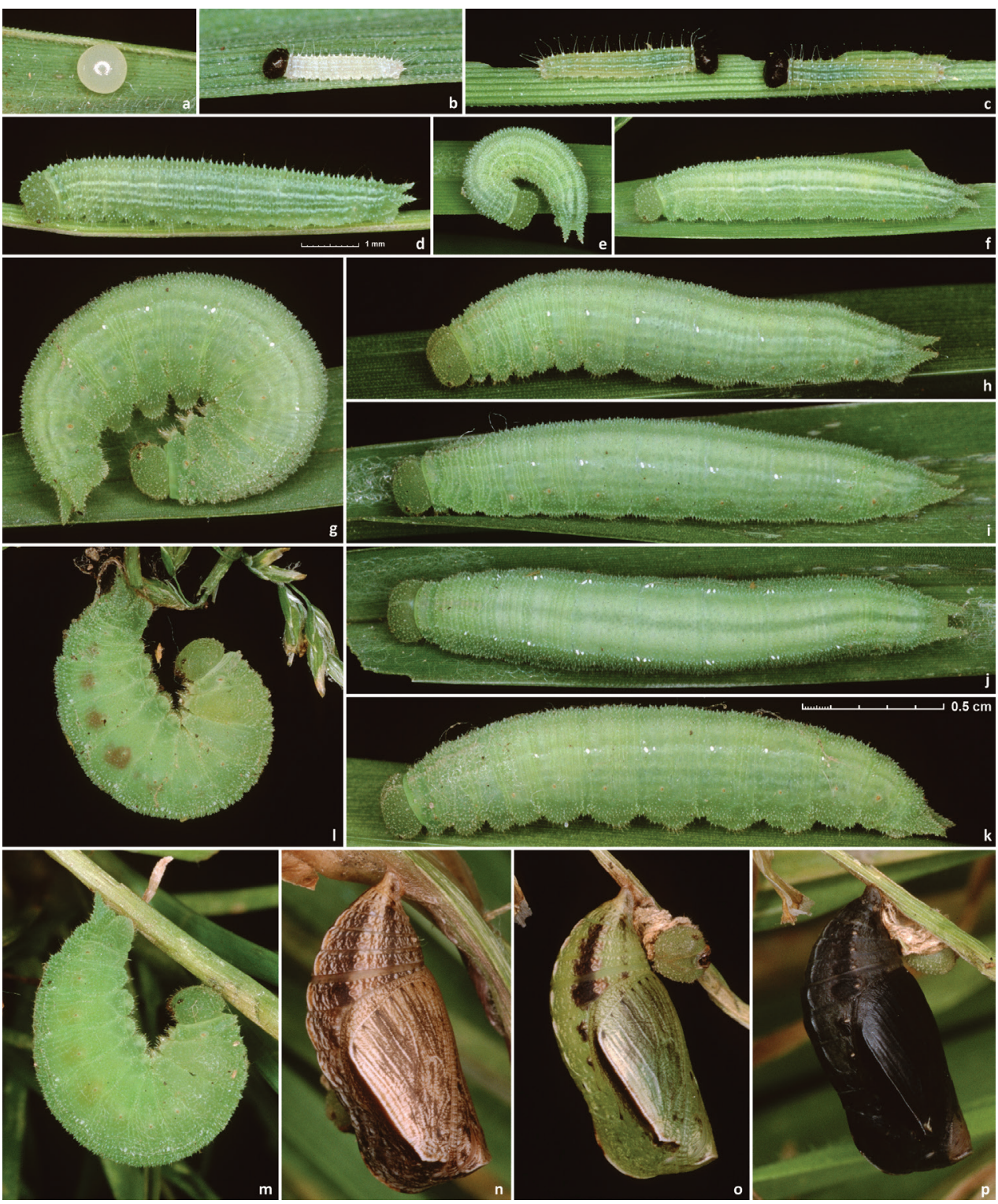

Figure 70. Life history of $H$. hermybius. USA: TX: Cameron County, E of Brownsville, ex ovum ex $q$ collected on 18-Jan-2003. a ovum, 23-Jan-2003 b-c 1t instars, photographed on 30-Jan \& 1-Feb-2003, respectively $\mathbf{b}$ prior to feeding, thus is white in color, $\mathbf{c}$ shows two caterpillars in a typical "head-to-head" resting position $\mathbf{d} 2^{\text {nd }}$ instar, $10-F e b-2003$ e-f $3^{\text {rd }}$ instars $14-\& 15-F e b-2003 \mathbf{~ g - k} 4^{\text {th }}$ (ultimate) instars, 25- 28- 26- 26- \& 25-Feb-2003 $\mathbf{g}$ is in a curled position adopted when disturbed; I- $\mathbf{m}$ prepupae, 26- \& 23-Feb-2003 n-p pupae, 10-Mar 25-Feb \& 4-Mar-2003 $\mathbf{n}$ is a brown form, shed larval skin is still attached near cremaster in $\mathbf{o}$ and $\mathbf{p}$ and is hanging behind the pupa in $\mathbf{n}, \mathbf{p}$ near eclosion, dark adult is seen through semi-transparent pupal cuticle. Most images show different individuals, those that eclosed are paratypes. Images a-d are enlarged 2 times (scale on $\mathbf{d}$ ) compared to the rest (scale on $\mathbf{k}$ ). 


\section{Discussion}

We pose and answer some questions that are likely to arise regarding our description of $H$. intricata and $H$. hermybius.

Can $\boldsymbol{H}$. intricata be identified by wing patterns alone? The sample of 20 barcoded and dissected $H$. intricata specimens from the type series (plus 2 more dissected paratypes without barcode sequences) is too small to judge with confidence. At the moment, it seems risky to accept wings-only identification. However, comparative analysis of wing patterns suggests the following three characters that should be investigated further (marked on representative specimens in Fig. 68). First, the postmedial dark-brown line on the ventral hindwing in $H$. intricata bulges distad near the vein $M_{3}$, in between the two smaller eyespots, closer to the posterior eyespot (e.g., compare Figs 32-47, 68). The line is more straight, or sinuous in H. sosybius, but frequently with a bulge anterior of the vein $\mathrm{M}_{3}$ (closer to large eyespot that is nearer the apex). Second, this line is relatively straight anterior of vein $\mathrm{M}_{2}$ in $H$. intricata, but is frequently bulged basad in $H$. sosybius. Third, in some $H$. intricata specimens, the postmedial dark-brown line on ventral forewing bends basad toward the costa (Fig. 68). More precisely, this line bends slightly distad towards the largest eyespot (in cell $\mathrm{M}_{1}$ $\mathrm{M}_{2}$ ) and then bends basad from near vein $\mathrm{M}_{1}$ (just anteriad of the largest eyespot) to costal margin. In H. sosybius, this line is typically straight or even bends distad towards costa. If the line bends basad, the bend is more gradual and begins posterior of $M_{1}$ vein (posteriad of the largest eyespot). However, in some $H$. intricata specimens this bend is not present (Figs 29, 31, 34, 41). If these hypothesized field marks are indeed meaningful, then an individual photographed by Tveten and Tveten (1996: 186) photograph reproduced with modifications in Brock and Kaufman (2003: 231, rightmost illustration) - is $H$. intricata. Judging from the title of the Tvetens' book, it was photographed in east Texas near Houston, which matches the expected distribution range of this species. Interestingly, another individual shown in Tveten and Tveten (1996: 178) on a full page photograph appears to be typical $H$. sosybius. To facilitate further identification of field marks, we illustrate almost the entire type series of $H$. intricata (Figs 22-35, 40-43, 68), and all DNA barcoded specimens of $H$. intricata and $H$. sosybius from the Brazos Bend State Park, Texas (Fig. 68).

Are DNA barcode sequences necessary for confident identification of $\mathrm{H}$. intricata? Although the DNA barcoding study has been instrumental in this project, we believe that its conclusions would hold without the knowledge of barcode sequences. Although we first noticed the difference in DNA barcodes, had we dissected the specimens prior to that, the presence of the two species $(H$. sosybius and $H$. intricata) and distinction between them would have become equally clear. We think male and female genitalia offer solid diagnostic characters that are sufficient for confident identification. These characters are numerous, are listed in the diagnosis above, and are illustrated in Figs 60-62 \& 64. Therefore, DNA barcode sequences are not required for confident identification of this new species. Nevertheless, barcodes were very valuable to suggest that south Texas $H$. sosybius-like populations with typically smaller, more uniform- 
ly-sized eyespots and more undulate ventral hindwing lines are not conspecific with eastern USA populations, but represent a new species, $H$. hermybius. DNA barcodes were equally valuable to confirm that the name $H$. hermes should be best reserved for a South American species (Seraphim et al. 2014).

Should $\boldsymbol{H}$. intricata be described now from a small sample? We believe that a description of a new species is an invitation to study it further. The discovery of a new butterfly species in the USA, especially rather distant evolutionarily from other members of the fauna (closest relatives in Bolivia and Brazil), is very exciting and should be made public without delays. It is interesting that the new species is cryptic in wing patterns, and its cryptic nature allowed it to remain unnoticed for over 200 years of research in butterfly taxonomy. Despite the small sample (type series of 22 specimens), we think that our taxonomic conclusions are solid, and genitalic differences are so pronounced that the species status of this taxon is fully justified. However, much remains to be studied, with the most obvious question being the distribution range of $\mathrm{H}$. intricata. We hope that our description will stimulate its future studies, including those by citizen scientists and butterfly enthusiasts. Thus we think it is beneficial to describe this new species right away.

Could $\boldsymbol{H}$. intricata be an extreme variation or a subspecies of $\boldsymbol{H}$. sosybius? These two taxa are sympatric and synchronic. They could be found flying together at exactly the same spot, with two individuals of different species landing on the same leaf. We think that prominent and easily observable differences in both male and female genitalia are sufficient to strongly support distinction between $H$. intricata and H. sosybius as species under essentially any species concept (De Queiroz 2007). Interestingly, even in the absence of barcode sequences, one can associate sexes of these two species correctly by matching morphology of their genitalia: both sexes of $H$. sosybius possess larger (for specimens of equal size) and less sclerotized genitalia, while both sexes of $H$. intricata are characterized by smaller and more sclerotized genitalia. This morphological match of genitalia suggests that the two butterflies are distinct biological species. Additionally, their DNA barcodes differ by 3.5\%, which indicates that the lineages were separated from each other by several million years and should be regarded as distinct evolutionary species.

Could $\boldsymbol{H}$. intricata be a northern subspecies of $\mathbf{H}$. gisella or $\boldsymbol{H}$. cucullina? DNA barcode distance tree (Fig. 66a) shows that $H$. intricata is in the same clade with $H$. cucullina and $H$. gisella (bootstrap support for the clade is about $60 \%$ ) and is more distant from sympatric $H$. sosybius. Even without the reconstructed tree, analysis of pairwise differences in DNA barcodes (Fig. 66a right, row and column 3 in the matrix) leads to the same conclusion: species closest to $H$. intricata are $H$. gisella (2.2\% difference) and $H$. cucullina (2.4\% difference). $H$. sosybius appears to be more distant at $3.4 \%$ difference. By genitalia, $H$. cucullina is quite different from the other species in its very short, thick and curved penis (Forster 1964, Seraphim et al. 2014). The penis in $H$. sosybius is more gracile. $H$. intricata and $H$. gisella share a shorter, similarly proportioned penis. However, in $H$. gisella the penis is strongly curved (Forster 1964, Seraphim et al. 2014), but in $H$. intricata the penis is bent only slightly, even less than in 
H. sosybius. Interestingly, DNA barcodes suggest that $H$. cucullina, despite its radically different penis, might be closer to $H$. gisella ( $1.7 \%$ difference), and $H$. intricata may be more distant from either of these two species (at least 2.2\%, Fig. 66). Although it is not clear whether $H$. intricata, $H$. gisella and $H$. cucullina are sympatric in any locality, differences in their genitalia and DNA barcodes argue that they are three biologically distinct species. However, all three form a species group and possibly are a superspecies (Amadon 1966). A comprehensive comparative study of DNA barcodes and male genitalia morphology by Seraphim et al. (2014) suggested a 2\% difference in barcodes of Hermeuptychia as a sensible indicator of species distinctness. DNA barcodes of $H$. intricata and $H$. gisella reveal a $2.2 \%$ difference. This difference coupled with differences in penis shape allow us to comfortably propose $H$. intricata as a new species.

Should the neotype for $\boldsymbol{H}$. sosybius be designated now? It is difficult to derive firm conclusions about taxa without firm identity. We think that it is not prudent to describe a new species sympatric with and hardly separable by wing patterns from $H$. sosybius without clarity about what the name $H$. sosybius stands for. Although the nature of Fabricius types of $H$. sosybius remains unclear and might never come to light, essentially everyone used and uses this name to refer to a common Hermeuptychia species widely distributed in the eastern US. Therefore it is sensible to stabilize this meaning by neotype designation. Data we gathered suggests which of the two US species should be $H$. sosybius (in the traditional use of the name) and a specimen of this species was selected as neotype.

What happened to $\boldsymbol{H}$. hermes for USA populations? We agree with Seraphim et al. (2014) that the name $H$. hermes should not be applied to USA Hermeuptychia populations. Described from Brazil: Rio de Janeiro (either Ilha Rasa or the city of Rio per G. Lamas, pers. comm.), $H$. hermes is characterized by very distinct genitalia, illustrated by Forster (1964: Abb. 60) and is easily distinguished from other Hermeuptychia species by valvae strongly constricted in the middle and a very long saccus (see Seraphim et al. 2014 for a photograph). DNA barcodes of specimens with this genitalia type do not group with $H$. sosybius-like barcodes in trees, and are more similar to $H$. maimoune instead (Fig. 66, Seraphim et al. 2014). H. hermes barcodes are over $4 \%$ different from any of close to 100 available Hermeuptychia barcodes from across the US. For instance, $H$. hermybius barcodes from south Texas are much closer to $H$. sosybius barcodes ( $2 \%$ different) than to $H$. hermes barcodes $(4.5 \%)$. Even $H$. intricata barcodes are closer to $H$. sosybius barcodes (3.4\%) than to $H$. hermes barcodes (4.5\%, see Fig. 66). The tree topology (Fig. 66a) is consistent with this distance analysis. As a summary, both male genitalia and barcodes indicate that the name $H$. hermes was incorrectly applied to USA populations. Widespread usage of the name $H$. hermes is simply a consequence of it being the oldest and a tendency to lump butterflies similar in wing patterns. Names that are presently considered junior subjective synonyms of $H$. hermes were proposed on the basis of South American specimens (Lamas 2004). While it will be necessary to clarify the status of these taxa by obtaining DNA barcodes or DNA ID tags from the primary type specimens and by designation of neotypes, it is very unlikely that any of these names could refer to USA Hermeuptychia populations. As DNA barcodes 
obtained in Seraphim et al. (2014) show, there is hardly any overlap between species at the northern and southern limits of Hermeuptychia range. Therefore, Hermeuptychia species from Surname is in all likelihood different from a Hermeuptychia species in Mexico.

Can $\boldsymbol{H}$. hermybius be identified by wing patterns alone? The $H$. hermybius type series of 101 specimens from all 5 Texas Counties bordering the Rio Grande from Laredo to Brownsville and northeastern Mexico (Tamaulipas \& San Luis Potosí) offers excellent material to study variation. This sample suggests that pattern-based identification using the three characters described in the diagnosis above is rather reliable, and $H$. hermybius (in contrast to $H$. intricata) could be mostly identified by wing patterns. Interestingly, while $H$. hermybius is much closer to $H$. sosybius phylogenetically than $H$. intricata, it seems easier to identify by wing patterns. Nevertheless, due to extreme variability of Hermeuptychia patterns, some specimens, especially those with smaller, underdeveloped eyespots and other elements of ventral hindwing pattern will not be identifiable by facies.

Are DNA barcode sequences necessary for confident identification of $\mathrm{H}$. hermybius? $H$. hermybius is a species very close to $H$. sosybius. Our analysis shows that the best characters to tell between the two species are indeed DNA barcodes (Fig. 66). However, we think that wing-based and male genitalia-based (using measurements and graph in Fig. 63) identification will be unambiguous in most cases without knowing the locality of a specimen. Nevertheless, it is likely that some specimens would not be identifiable with confidence in the absence of DNA barcodes.

Could $\boldsymbol{H}$. hermybius be a southern subspecies of $\boldsymbol{H}$. sosybius? In our opinion, consistency between the differences in DNA barcodes, wing patterns, male genitalia and historic treatment of south Texas populations as a distinct species by several authors (Miller and Brown 1981, brief comment in Neck 1996, Pelham 2008, Warren et al. 2013), although under the incorrect name " $H$. hermes", argues for the species status of this taxon. We see a prominent $2 \%$ difference hiatus in DNA barcodes between central Texas and south Texas Hermeuptychia populations (Figs 66-67) and very little variation in barcodes of $H$. sosybius across its range from North Carolina to Florida and central Texas. This DNA barcode hiatus correlates with the wing pattern differences: smaller and more uniformly sized eyespots, more wavy brown lines in south Texas populations; and with male genitalia differences that were quantified on a diverse sample (Fig. 63). Finally, without knowing DNA barcodes, experienced butterfly taxonomists who were quite familiar with Satyr butterflies, in particular Miller and Brown (1981), listed USA Hermeuptychia populations as two species. However, it remains unknown whether $H$. hermybius and $H$. sosybius are sympatric, and the region between the Lower Rio Grande Valley and central Texas should be explored for possible areas of sympatry.

Is there a specimen age limit for successful DNA barcoding? The oldest specimens we succeeded with were about 120 years old. These were the oldest specimens we tried. We see that DNA fragments into smaller pieces with age. Therefore, for successful amplification, primers for shorter DNA segments should be designed. Per 
Materials and methods section, we developed primers for two very short (75 bp and shorter) segments of DNA that contain the highest density of differences between the three US Hermeuptychia species. We called these regions ID tags. These tags were successfully and consistently amplified from over 100 years old specimens. Example of the results is shown in Fig. 65. The ID tags allowed us to identify these specimens by DNA and these identifications always matched genitalic identifications. This method could be applied to older specimens and is expected to yield similar success. Potentially, even the oldest preserved butterfly specimen could contain usable DNA that can be extracted and amplified with current methods.

What could be the English name for $\boldsymbol{H}$. intricata and $\boldsymbol{H}$. hermybius? Although some object to using "common" names for butterflies (i.e. the names in the native language of a country the insect inhabits), especially in research publications, we believe that common names are beneficial to attract public interest to butterflies and to disseminate knowledge about them more efficiently, thus possibly aiding their conservation. We suggest "Intricate Satyr" as the English name for $H$. intricata to indicate its delicate wing patterns, cryptic nature, difficulty of identification, and the fact that it has remained overlooked in over 200 years of exploration of North American butterflies despite very significant differences in genitalia. We propose the English name "South Texas Satyr" for $H$. hermybius to emphasize its type locality and distribution in the US, and to highlight the importance of South Texas in the studies of butterfly fauna.

\section{Acknowledgments}

Qian Cong is a Howard Hughes Medical Institute International Student Research fellow. We acknowledge Texas Parks and Wildlife Department (Natural Resources Program Director David H. Riskind) for the permit \#08-02Rev making research based on material collected in Texas State Parks possible. We are grateful to Edward G. Riley (Texas A \& M University insect collection, College Station, TX), Robert K. Robbins, John M. Burns and Brian Harris (National Museum of Natural History, Smithsonian Institution, Washington DC), David Lees and Blanca Huertas (Natural History Museum, London, UK), for facilitating access to the collections under their care and stimulating discussions; to Bill Dempwolf for collecting part of the $H$. hermybius type series; to André V. L. Freitas (Instituto de Biologia, Universidade Estadual de Campinas, Campinas, SP Brazil) and Jonathan P. Pelham for fruitful discussions; to John V. Calhoun for information about historic facts and literature; to Jude Philp and Robert Blackburn (Macleay Museum, The University of Sydney, Sydney, Australia) for discussions of Macleay collection and photographs of possible H. sosybius syntypes; to Kathleen Santry (Oxford University Museum of Natural History, Oxford, UK) for the images of $H$. sosybius illustrations by Jones; Peter N. Grishin for assistance with translations from Latin; Ralf H. Anken for sending the holotypes of Hermeuptychia taxa described by him and many useful discussions; to Gerardo Lamas (Museo de Historia Natural, Universidad Nacional Mayor de San Marcos, Lima, Peru) for most helpful 
discussions, critical review of the manuscript and insightful suggestions that lead to significant improvement of this work, to Kim Garwood, Bryan Reynolds and Brian Banker for reading the manuscript and corrections, and to the reviewers for helpful comments and suggestions.

\section{References}

Allen TJ (1997) The butterflies of West Virginia and their caterpillars. University of Pittsburgh Press, 388 pp.

Altschul SF, Gish W, Miller W, Myers EW, Lipman DJ (1990) Basic local alignment search tool. Journal of Molecular Biology 215(3): 403-410.

Amadon D (1966) The superspecies concept. Systematic Biology 15(3): 245-249. doi: 10.2307/sysbio/15.3.245

Anken RH (1993) Bemerkungen zu Hermeuptychia hermes Fabricius im Südosten Nordamerikas (Lepidoptera: Satyridae). Entomologische Zeitschrift 103(22): 415-419.

Benson DA, Cavanaugh M, Clark K, Karsch-Mizrachi I, Lipman DJ, Ostell J, Sayers EW (2013) GenBank. Nucleic Acids Research 41(Database issue): D36-D42. doi: 10.1093/ nar/gks1195

Bickford D, Lohman DJ, Sodhi SH, Ng PKL, Meier R, Winker K, Ingram KK, Das I (2007) Cryptic species as a window on diversity and conservation. Trends in Ecology \& Evolution 22(3): 148-155. doi: 10.1016/j.tree.2006.11.004

Brock JP, Kaufman K (2003) Butterflies of North America. Hillstar Editions L. C., New York, 384 pp., Figs, maps.

Calhoun JV (1997) Updated list of the butterflies and skippers of Florida (Lepidoptera: Papilionoidea and Hesperioidea). Holarctic Lepidoptera 4(2): 39-50.

Calhoun JV (2006) A glimpse into a "Flora et Entomologia": The Natural History of the Rarer Lepidopterous Insects of Georgia by J. E. Smith and J. Abbot (1797). Journal of the Lepidopterists' Society 60(1): 1-37.

De Queiroz K (2007) Species concepts and species delimitation. Systematic Biology 56(6): 879-886. doi: 10.1080/10635150701701083

Dereeper A, Guignon V, Blanc G, Audic S, Buffet S, Chevenet F, Dufayard JF, Guindon S, Lefort V, Lescot M, Claverie JM, Gascuel O (2008) Phylogeny.fr: robust phylogenetic analysis for the non-specialist. Nucleic Acids Research 36(Web Server issue): W465-W469.

DeVries PJ (1989) I remember Gordon. Journal of the Lepidopterists' Society 43(4): 343-345.

Fabricius JC (1793) Entomologia systematica emendata et aucta. Secundum classes, ordines, genera, species adjectis synonimis, locis, observationibus, descriptionibus. Hafniae, Christian Gottlieb Proft, Fil. et Soc. 3(1): [vi] + 488 pp.

Field WD (1967) Preliminary revision of butterflies of the genus Calycopis Scudder (Lycaenidae: Theclinae). Proceedings of the United States National Museum 119(3552): 1-48. doi: 10.5479/si.00963801.119-3552.1

Forster W (1964) Beiträge zur Kenntnis der Insektenfauna Boliviens XIX. Lepidoptera III. Satyridae. Veröffentlichungen der zoologischen Staatssammlung München 8: 51-188. 
Gascuel O (1997) BIONJ: an improved version of the NJ algorithm based on a simple model of sequence data. Molecular Biology and Evolution 14(7): 685-695. doi: 10.1093/oxfordjournals.molbev.a025808

Glassberg J (2007) A Swift guide to the butterflies of Mexico and Central America. Sunstreak Books, Inc., Morristown, [vi] + 266 pp., Figs.

Glassberg J, Minno MC, Calhoun JV (2000) Butterflies through binoculars: a field, finding, and gardening guide to butterflies in Florida. Oxford University Press, Oxford, viii + 242 pp., 44 pls., Figs, 3 tabs, maps.

Grishin NV, Durden CJ (2012) New Bromeliad-feeding Strymon species from Big Bend National Park, Texas, USA and its vicinity (Lycaenidae: Theclinae). Journal of the Lepidopterists' Society 66(2): 81-110.

Hebert PDN, deWaard JR, Landry J-F (2010) DNA barcodes for 1/1000 of the animal kingdom. Biology Letters 6(3): 359-362. doi: 10.1098/rsbl.2009.0848

Howe WH (1975) The butterflies of North America. Doubleday \& Company, Inc., New York, xiii +633 pp., 97 pls., 32 Figs.

ICZN (International Commission on Zoological Nomenclature) (1999) International Code of Zoological Nomenclature, Fourth Edition. International Trust for Zoological Nomenclature, London, xxix + 306 pp. Online version amended "with effect from 1 January 2012" http://www.nhm.ac.uk/hosted-sites/iczn/code/ [accessed January 12, 2014]

Kimura M (1980) A simple method for estimating evolutionary rate of base substitutions through comparative studies of nucleotide sequences. Journal of Molecular Evolution 16: 111-120. doi: 10.1007/BF01731581

Lamas G (2004) Satyrinae. In: Heppner JB (Ed) Checklist: Part 4A. Hesperioidea-Papilionoidea. Atlas of Neotropical Lepidoptera. Association for Tropical Lepidoptera/Scientific Publishers, Gainesville, Florida, 220 pp.

Miller LD, Brown FM (1981) A catalogue/checklist of the butterflies of America north of Mexico. Memoir. The Lepidopterists' Society 2: vii + 280 pp.

Murray D, Prowell DP (2004) Molecular phylogenetics and evolutionary history of the neotropical Satyrine Subtribe Euptychiina (Nymphalidae: Satyrinae). Molecular Phylogenetics and Evolution 34(1): 67-80. doi: 10.1007/BF01731581

Neck R (1996) A field guide to butterflies of Texas. Gulf Publishing Company, Houston, Texas, xvii +323 pp.

Nicolay SS (1989) Obituary: Gordon Burgess Small, Jr. (1934. 1989). Journal of the Lepidopterists' Society 43(4): 340-343.

Opler PA, Krizek GO (1984) Butterflies east of the Great Plains. An illustrated natural history. The Johns Hopkins University Press, Baltimore and London, xvii + 294 pp., 54 pls., 38 Figs, 11 tabs.

Opler PA, Lotts K, Naberhaus T (coordinators) (2013) Butterflies and moths of North America. http://www.butterfliesandmoths.org/ (Version 10052013)

Opler PA, Malikul V (1992) A field guide to eastern butterflies. Houghton Mifflin Company, Boston, xix + 396 pp., 48 pls., 7 Figs, maps.

Opler PA, Warren AD (2002) Butterflies of North America. 2. Scientific names list for butterfly species of North America, north of Mexico. Colorado State University, C. P. Gillette Museum of Arthropod Diversity, Fort Collins, [2] + 79 pp. 
Pelham JP (2008) A catalogue of the butterflies of the United States and Canada with a complete bibliography of the descriptive and systematic literature. Journal of Research on the Lepidoptera 40: i-xiii, 1-652.

Peña C, Nylin S, Freitas AVL, Wahlberg N (2010) Biogeographic history of the butterfly subtribe Euptychiina (Lepidoptera, Nymphalidae, Satyrinae). Zoologica Scripta 39: 243-258. doi: 10.1111/j.1463-6409.2010.00421.x

Robbins RK (1991) Evolution, comparative morphology, and identification of the Eumaeine butterfly genus Rekoa Kaye (Lycaenidae: Theclinae). Smithsonian Contributions to Zoology 498, 64 pp.

Robbins RK, Lamas G (2006) Stabilizing the nomenclature of fabrician names of North American hairstreaks (Lycaenidae: Theclinae: Eumaeini). Journal of the Lepidopterists' Society 60(2): 86-91.

Scott JA (1986) The butterflies of North America. A natural history and field guide. Stanford University Press, Stanford, xv + 583 pp., 64 pls., 71 Figs, 2 tabs, maps.

Seraphim N, Marín MA, Freitas AVL, Silva-Brandão KL (2014) Morphological and molecular marker contributions to disentangling the cryptic Hermeuptychia hermes species complex (Nymphalidae: Satyrinae: Euptychiina). Molecular Ecology Resources 14(1): 39-49. doi: $10.1111 / 1755-0998.12161$

Silva-Brandão KL, Lyra ML, Santos TV, Seraphim N, Albernaz KC, Pavinato VAC, Martinelli S, Cônsoli FL, Omoto C (2011) Exploitation of mitochondrial nad6 as a complementary marker for studying population variability in Lepidoptera. Genetics and Molecular Biology 34(4): 719-725. doi: 10.1590/S1415-47572011000400028

Smith AZ (1986) A history of the Hope Entomological Collections in the University Museum, Oxford with lists of Archives and Collections. Clarendon Press, Oxford, xiii + 172 pp.

Steinhauser SR (1981) A revision of the proteus group of the genus Urbanus Hübner. Lepidoptera: Hesperiidae. Bulletin of the Allyn Museum 62: 1-41.

Tveten JL, Tveten GA (1996) Butterflies of Houston and Southeast Texas. University of Texas Press, Austin, $\mathrm{x}+292 \mathrm{pp}$.

Vane-Wright RI (2010) William Jones of Chelsea (1745-1818), and the need for a digital, online 'Icones'. Antenna 34(1): 16-21.

Warren AD, Davis KJ, Stangeland EM, Pelham JP, Grishin NV (2013) Illustrated Lists of American Butterflies. http://www.butterfliesofamerica.com [accessed 30.XII.2013]

Zakharov EV, Lobo NF, Nowak C, Hellmann JJ (2009) Introgression as a likely cause of mtDNA paraphyly in two allopatric skippers (Lepidoptera: Hesperiidae). Heredity (Edinburgh) 102(6): 590-599.

Zimsen E (1964) The type material of I. C. Fabricius. Copenhagen, Munksgaard, 656 pp., 3 Figs. 